(2) institute of development studies

Working Paper

Volume 2021 Number 554

Demanding Power:

Struggles over Fuel Access

in Nigeria

Martin Atela, Ayobami Ojebode, Tade Aina, John Agbonifo, Marjoke Oosterom, Racheal Makokha, Oluwabusolami Oluwajulugbe and Omeghie Okoyomoh

August 2021 
The Institute of Development Studies (IDS) delivers world-class research, learning and teaching that transforms the knowledge, action and leadership needed for more equitable and sustainable development globally.

Action for Empowerment and Accountability (A4EA) is an international research programme which explores how social and political action can contribute to empowerment and accountability in fragile, conflict, and violent settings, with a particular focus on Egypt, Mozambique, Myanmar, Nigeria, and Pakistan.

Led by the Institute of Development Studies, A4EA is being implemented by a consortium which includes: the Accountability Research Center, the Collective for Social Science Research, the Institute of Development and Economic Alternatives, Itad, Oxfam GB, and the Partnership for African Social and Governance Research.
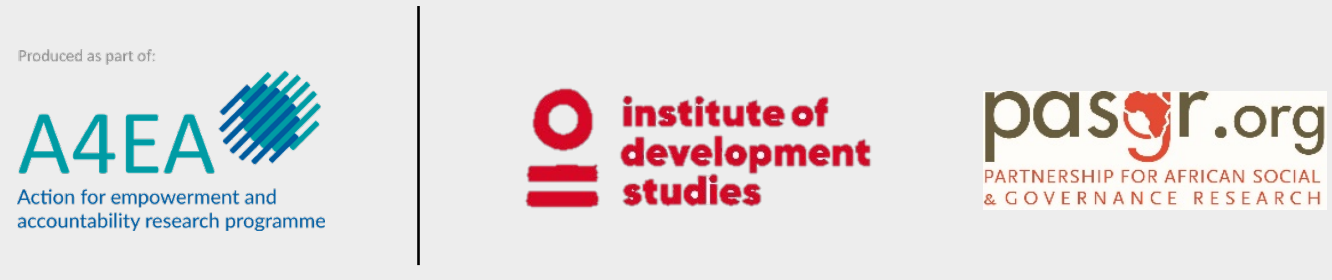

(C) Institute of Development Studies 2021

Working Paper Volume 2021 Number 554

Demanding Power: Struggles over Fuel Access in Nigeria

Martin Atela, Ayobami Ojebode, Tade Aina, John Agbonifo, Marjoke Oosterom, Racheal Makokha,

Oluwabusolami Oluwajulugbe and Omeghie Okoyomoh

August 2021

First published by the Institute of Development Studies in August 2021

ISSN: 2040-0209 ISBN: 978-1-78118-842-2

DOI: $10.19088 / I D S .2021 .054$

Suggested citation: Atela, M. et al. (2021) Demanding Power: Struggles over Fuel Access in Nigeria, IDS Working Paper 554, Brighton: Institute of Development Studies, DOI: 10.19088/IDS.2021.054

A catalogue record for this publication is available from the British Library

This paper is funded with UK aid from the UK government (Foreign, Commonwealth \& Development Office FCDO, formerly DFID). The opinions are the authors and do not necessarily reflect the views or policies of IDS or the UK government.

This is an Open Access paper distributed under the terms of the Creative Commons Attribution 4.0 International licence (CC BY), which permits unrestricted use,

distribution, and reproduction in any medium, provided the original authors and source are credited and any modifications or adaptations are indicated.

Available from:

Institute of Development Studies, Library Road

Brighton, BN1 9RE, United Kingdom

+44 (0)1273915637

ids.ac.uk

IDS is a charitable company limited by guarantee and registered in England

Charity Registration Number 306371

Charitable Company Number 877338 
Working Paper

Volume 2021 Number 554

Demanding Power:

Struggles over Fuel Access

in Nigeria

Martin Atela, Ayobami Ojebode, Tade Aina, John Agbonifo, Marjoke Oosterom, Racheal Makokha, Oluwabusolami Oluwajulugbe and Omeghie Okoyomoh August 2021 


\section{Demanding Power: Struggles over Fuel Access in Nigeria}

Martin Atela, Ayobami Ojebode, Tade Aina, John Agbonifo, Marjoke Oosterom, Racheal Makokha, Oluwabusolami Oluwajulugbe and Omeghie Okoyomoh

\section{August 2021}

\section{Summary}

Why do some fuel protests in Nigeria lead to a response from government, but others are barely noticed? What are the politics behind government response and who are the winners and losers? Using a multi-method approach, this study focuses on the period between 2007-2017 to investigate the dynamics of fuel protest in Nigeria to ask how, and under which conditions, struggles over energy access in Nigeria produce accountability and empowerment.

Although the protests on energy access have elicited some response from the government (accountability) such as a short-term downward review of fuel prices, they have hardly ever led to any long-term organisational or structural changes nor do they benefit, maximally, the marginalised and less powerful who form the bulk of the protesters. Instead, the protests can become a platform for opposition politicians who capitalise on government failure to push their own political agendas in an attempt to wrest power. Because the protests require some level of organising and material provisioning to be effective, those who possess these skills and resources may prioritise their own interests. As a result, citizens feel disempowered as they are convinced the government is inaccessible.

The findings suggest that accountability and empowerment outcomes of the struggles over fuel access in Nigeria are severely limited by the very conditions that define the state as fragile: weak institutions, elite capture, widespread corruption, and a citizenry that is protest-fatigued and disempowered. This could be true of other fragile and conflict-affected settings. Therefore, frameworks that open up the civic space for dialogues between the government and citizens may produce better outcomes than protests.

\section{Keywords}

Nigeria; accountability; empowerment; energy struggles; fuel protests; fuel subsidies; fragile settings. 


\section{Authors}

Martin Atela (PhD) is a research scientist with interests in accountability and governance, health systems strengthening, community engagement, and mixedmethods approaches to complex research. Martin heads the Research and Policy programme at the Partnership for African Social and Governance Research (PASGR - Kenya). He earned his PhD from the University of Cambridge, UK and is Gates Cambridge Alumnus.

Ayobami Ojebode (PhD) is Professor of Applied Communication and Head, Department of Communication \& Language Arts, University of Ibadan, Nigeria. His research interests are community communication; community governance; new media; and political communication. He was the Nigeria country lead for the first phase of the A4EA work which focused on the Bring Back Our Girls movement, and the Principal Investigator for the DFID-funded Evidence and Lessons from Latin America (Phase II) study which focused on communitybased crime prevention in Africa and Latin America. He is skilled in policyengaged research, multidisciplinary and mixed-method research, and research skills training and development.

Tade Akin Aina (D. Phil) is the former Executive Director of PASGR. Formerly he was Program Director of Higher Education and Libraries in Africa for the Carnegie Corporation of New York from 2008 to 2014. He was a Professor of Sociology at the University of Lagos and has served as a consultant for many agencies including UNDP, UNICEF, UN-HABITAT and the United Nations University. He is an author, co-author, editor and co-editor of eleven books and monographs and recently co-edited, with Bhekinkosi Moyo, Giving to Help, Helping to Give: The Context and Politics of African Philanthropy (Amalion Publishing).

John Agbonifo (PhD) is a Reader, and Acting Director of the Global Affairs and Sustainable Development Institute (GASDI), Osun State University, Osogbo, Nigeria. With a background in development studies, his research interests centre on conflicts attendant on environmental transformations mediated by multinational oil corporations. He explores the themes from a sub-Saharan African perspective, focusing in particular on grassroots collective action, transparency and accountability in the extractive industry in the Niger Delta. He has also worked on non-state armed actors and the use of UN and regional sanctions to promote international security. He has several publications, including his latest book, Environment and Conflict: the Place and Logic of Collective Action in the Niger Delta (Routledge).

Marjoke Oosterom (PhD) is a Research Fellow at the Institute of Development Studies (IDS). With a background in comparative politics and international development studies, her research concentrates on the effects of political 
violence, repression and armed conflict on forms of agency, citizenship and identity, in Sub Saharan Africa. Marjoke Oosterom's specific expertise is in youth politics; and she has a portfolio of research projects on young people's experiences of marginalisation and insecurity; citizenship and civic and political engagement; and political networks in the informal economy. She has been involved in advisory work for policy makers and international NGOs working on democratic governance, conflict, and youth. She is the principal investigator on an ESRC-funded project on youth and political socialisation in the informal economy in Zimbabwe, and a British Academy-funded project on workplace sexual violence in Uganda and Bangladesh.

Rachael Makokha (MSc) holds a master's degree in International Political Economy and Development from the University of Birmingham (UK). She is a Tutorial Fellow at the Technical University of Kenya and a Research Associate with PASGR. Her research interests are in political economy, governance, and security studies.

Oluwabusolami Oluwajulugbe (MA) is a doctoral student of the Department of Communications and Language Arts, University of Ibadan. For her MA, she employed action research to address extreme infrastructural deficit in a public school in lbadan. For her $\mathrm{PhD}$, she is studying if and how community radio stations in Nigeria empower women listeners for social action. Passionate about welfare and development matters, she has participated in several projects on popular protests and their outcomes. These included the Bring Back Our Girls study by PASGR.

Omeghie Okoyomoh (MA) holds a master's degree in Communication and Language Arts from the University of Ibadan, Nigeria. Twice she has been involved in the study of protests and their consequences. These included the Bring Back Our Girls study by PASGR. Her research focuses on communication for development and the different ways in which information resources can be used to improve intervention outcomes within African communities. She is keen on strategic communication processes and the use of media tools and interpersonal interaction to promote participation and co-operation among stakeholders in development projects. 


\section{Contents}

Acknowledgements

1. Introduction

$1.1 \quad$ Background

1.2 Country context: Energy access and use in Nigeria

1.3 Historical overview: Fossil fuels and protests in Nigeria

2. Methodology

$2.1 \quad$ Methods

2.2 Sampling

2.3 Data collection procedure

2.4 Validation of the research procedure

$2.5 \quad$ Ethics

3. Fragility, social contract, and the escalation of energy struggles

3.1 Nigeria, fragility and fuel subsidies

3.2 Escalation of fuel subsidy struggles into major episodes of contention in Nigeria 25

3.2.1 Popular culture and the energy protests

3.3 Understanding attitudes to fuel subsidies in Nigeria

3.4 Political and civic space and popular engagement with fuel price 
4.1 The 2012 protest dynamics

4.2 Legal accountability and reforms

5. Popular protests and empowerment over policymaking on energy provisioning

6. Transnational actors and the contentious political economy of energy

7. Conclusions

7.1 What leads to the escalation of protests?

7.2 Do protests result in, or support, accountability and/or empowerment?

7.3 What role do international actors play in these crises?

7.4 Lessons on action for empowerment and accountability

\section{Tables}

Table 1.1 Attempts to remove or reduce subsidy by different Nigerian administrations

Table 2.1 Details of focus group discussions

Table 3.1: Protest episodes: 2007 to 2017

Table A1 Chronicle of fuel-related protects in Nigeria

Table A2 Not all fuel price increases attracted protests: 2007-20 


\section{Acknowledgements}

The authors are grateful to the following for their helpful support during fieldwork: focus group participants, key informant interviewees, participants at the inception workshop, and the external reviewers.

The authors thank Naomi Hossain, John Gaventa, Damilola Adebayo, Adeshina Afolayan and Neil McCulloch for their critical reviews and helpful suggestions. Responsibility for any errors is the authors'.

\section{Acronyms}

$\begin{array}{ll}\text { CSO } & \text { civil society organisation } \\ \text { EFCC } & \text { Economic and Financial Crimes Commission } \\ \text { EITI } & \text { Extractives Industries Transparency Initiative } \\ \text { FGD } & \text { focus group discussion } \\ \text { IMF } & \text { International Monetary Fund } \\ \text { KII } & \text { key informant interviews } \\ \text { MW } & \text { megawatt } \\ \text { NNPC } & \text { Nigeria National Petroleum Corporation } \\ \text { PMS } & \text { Petroleum Motor Spirit } \\ \text { PPPRA } & \text { Petroleum Products Pricing and Regulatory Agency }\end{array}$




\section{Introduction}

In Nigeria, why have some protests about fossil fuel access or price led to a shift in government policy or position, while others have barely been noticed? Why have some turned into major episodes of popular resistance in the past decade, despite sometimes heavy-handed repression from the government? What accounts for the different types of government response to these energy protests? To what extent have these protests led to accountability in government? This paper presents findings from a study of episodes of protests in Nigeria, with an emphasis on the period between 2007 and 2017. The history of Nigeria, both under military dictatorship and the commencement of democratic rule in 1999, is the history of how energy, particularly fossil fuels, has shaped politics and conflicts (Lewis 2018). Since the early 1970s, there have been more than thirty attempts by the Nigerian government to increase the price of petrol, each sparking popular protests of varying degrees (see Table 1.1), some attracting thousands of people in various locations across the country, including Lagos, Kaduna, Benin City, and Kano.

This study investigated the key drivers of the protests, as well as the outcomes, focusing on negotiations and contentions over fossil fuel subsidies and their effects on accountability and empowerment. It is part of the Action for Empowerment and Accountability (A4EA) programme's 'Demanding Power' research project. A4EA is an international research collaboration exploring how social and political action contributes to empowerment and accountability in fragile, conflict, and violent contexts. The Demanding Power project, carried out in Mozambique, Nigeria and Pakistan has been designed to understand how and under which conditions struggles over energy access in fragile and conflictaffected settings empower people to hold public authorities to account. By 'access' we refer to both affordability and availability. The research has the objective of deepening and diversifying the body of evidence on the contexts in which contentions and negotiations over energy occur, how these are framed in popular narratives, and what collective, individual, national and international interests are at play.

The paper consists of seven sections. Section 1 introduces the research and provides contextual information on the study country - Nigeria. Section 2 lays out the methodology applied to address the research questions, including how these were adapted to the Nigerian context. Section 3 looks at why struggles around energy in Nigeria specifically appear to have the potential to grow into significant episodes of contention. Consideration is given to what issues make the Nigerian context fragile and how these are intertwined with energy struggles driven by the billion-dollar fuel subsidy regime. Section 4 assesses whether popular struggles in Nigeria have strengthened government accountability concerning energy 
access. In section 5, the study examines whether struggles over fuel pricing and subsidies caused a shift that favours ordinary citizens in terms of energy provisioning policies. Section 6 reviews the role of several transnational actors in Nigeria's political economy of fuel subsidies. Section 7 summarises the study findings, providing an overall evaluation of the accountability and empowerment effects of energy struggles, and concluding with the study findings' implications in the broader context of global and national fossil fuel subsidy reforms and energy sector governance.

\subsection{Background}

Across the world, energy prices, subsidies, and availability have very often become flashpoints for social mobilisation, protest, and demands for government accountability. These issues have found recent expression in the gilet jaune movement in France, and in passionate protests in Zimbabwe. In state contexts characterised by fragility, conflict and violence, some evidence suggests that such protests may take on a particular character, have distinct meanings, and may play a role in wider understandings and expressions of accountability (Hossain and Scott-Villiers 2017). However, there is limited academic evidence specifically on popular struggles around energy access in developing countries. We know particularly little about whether and how these struggles and actions contribute to the long-term capacity of citizens to hold states to account.

Building on available evidence, this study investigated how access to energy acts as a conduit for social and political mobilisation in fragile and conflictaffected contexts. Its aim is to:

- Deepen our understanding of the salience of energy access amongst poor and excluded people in low-income contexts;

- Expand understandings of contentious and unruly politics, and what has been termed 'the politics of provisions' - the place that access to certain goods takes in the bargain between the people and public authorities, often in the absence of a wider social contract on rights, services, and public goods;

- Grow the understanding of the political economy of energy reforms - an area of substantial policy interest.

The evidence generated in this research should inform any reforms on fuel subsidies in Nigeria given the broad national and global policy consensus against fossil fuel subsidies on both ecological and economic grounds. The evidence could support ongoing efforts in Nigeria to reform the oil sector including the withdrawal of fuel subsidies. 


\subsection{Country context: Energy access and use in Nigeria}

Nigeria is Africa's most populous country with an estimated population of 200 million (NBS 2018), and its largest economy with a gross domestic product of over US\$398 billion in 2018 (IMF 2019a). It is Africa's largest oil producer and the sixth largest producer of oil and gas in the world. It holds an estimated oil reserve of 36.2 billion barrels, and vast proven natural gas reserves ${ }^{1}$ located mainly along the Niger Delta, Gulf of Guinea, and Bight of Bonny. Oil and gas are Nigeria's key drivers of economic growth and development, supporting job creation, revenue generation, and foreign exchange earnings through exports.

Although Nigeria is a major producer, it is unable to refine its crude oil to meet local demand. As a result, it resorts to exporting its crude oil and importing refined products. The landing and pump prices of these products are too high for most people to afford. This is because about 54 per cent of Nigerians are described as 'multidimensionally poor' and inequality remains a hallmark of the country's socioeconomic development: Nigeria ranks 152 out of 187 in inequality rankings (MPPN 2018). Given the importance of petroleum products for socioeconomic growth, the Nigerian government has historically subsidised the prices of imported petroleum products. Thus, fuel subsidies became a major social welfare scheme that Nigerians enjoy.

However, the process of providing subsidies involves multiple actors: the government, its parastatal in charge of petroleum, importers, distributors, final vendors, and consumers. The process is not only complex, but also shrouded in opaque dealings. Ordinary citizens, trade unions, the media, and a range of interest groups have come to believe that subsidies are essential public benefits and are, therefore, heavily invested both politically and commercially in government regulatory actions. The politics of petroleum subsidies in Nigeria is not only contentious, but also volatile because it is often linked to the unequal distribution of oil wealth across individual, ethnic, and regional lines. The bitter nature of fuel subsidy politics at both the personal and structural levels has been acknowledged by important Nigerian political figures such as President Goodluck Jonathan and the former Minister of Finance, Dr Ngozi Okonjo-Iweala (Jonathan 2018; Okonjo-Iweala 2018).

Yet, crude oil and natural gas do not constitute the only sources of energy in a country as resource-rich as Nigeria. There is a large reserve of other nonrenewable energy resources including coal and nuclear fuels. The country is also endowed with renewable energy sources including biomass, hydropower, solar,

Authorities disagree widely on the estimated proven gas reserves in Nigeria: OPEC (2020) says it is over 5,000 billion cubic metres while Nigeria's Department of Petroleum Resources (DPR 2020) claim it is about 203 trillion cubic feet which is about 5,000 billion cubic metres. However, while these details differ, the overall point is that these reserves are vast. 
and wind power, all of which could contribute to Nigeria's capacity to be energy sufficient (Ighodaro 2010). Despite these vast energy resources and the wealth generated from their appropriation, Nigerians continue to experience energy shortages. The gap between energy supply and demand has been attributed to inadequate development and poor management of the energy sector (Oyedepo 2012). A critical example of this is the highly deficient on-grid electricity supply system. Although recent efforts have been made by the government to boost electricity generation, Nigeria's current total installed capacity is 12,522 megawatts (MW), of which 10,142MW is thermal (mainly powered by oil or gasfired plants), and 2,380MW is from hydroelectric sources (USAID 2020).

To put this into context, South Africa, a country with about 58 million people, despite its ongoing electricity challenges, has a total installed capacity of 58,095MW (USAID 2021). In fact, the most recent World Bank data, disaggregated based on kilowatt-hours per capita in countries, indicates that the average South African citizen uses thirty times more energy than the average Nigerian (World Bank 2014). Access to electricity in Nigeria, though characterised by unstable supply and frequent cuts, has gradually increased from 40 per cent of the population in 2000 to 60 per cent of the population in 2018 (Lighting Africa 2019). However, there is a rural-urban divide. Only 41.1 per cent of people living in rural areas have access to electricity compared to 86 per cent of those living in urban areas (Lighting Africa 2019). This demonstrates that the poorest and most vulnerable Nigerians, who constitute the majority of the population, are also the most affected by an inadequate supply of electricity. Energy needs and access in Nigeria vary along socio-economic status, residence (rural versus urban), regional divides (northern versus southern Nigeria), as well as gender. The secondary and tertiary sectors of the Nigerian economy, for instance manufacturing and transportation, rely heavily (though not exclusively) on petroleum products for their energy requirements. Many Nigerians, especially urban residents, are forced to invest in inefficient and dangerous diesel-powered or petrol-powered generators, as well as kerosene stoves, for their commercial and domestic energy needs. In 2021, Nigeria's daily petrol consumption was estimated at 93 million litres (Oladipo 2021). This consumption is higher than any other African country. However, a majority of households in rural areas rely on fuel wood for cooking. An estimated 50 million plus tonnes of fuel wood are used annually in Nigeria, largely supplied by sellers operating within the informal economy (Oyedepo 2012; NBS 2018).

The overreliance on unclean and unregulated energy sources by rural households is not only cultural, dating back centuries, but is also caused by the unreliable supply and high cost of petroleum products in rural areas. In some cases, the cost of petroleum products such as kerosene and gasoline in rural areas is estimated to be in excess of 150 per cent of official pump prices 
(Oyedepo 2012), an indication that fuel subsidies and reforms do not always achieve the desired impact.

The impact of the high costs is felt most by women. A recent large-scale survey assessing the gendered impacts of fossil fuel subsidy reform in Nigeria found that while subsidies directed at kerosene and liquefied petroleum gas (LPG) did bring down the official prices, hoarding and other sharp practices keep the price that women pay for these items high. In fact, some women pay two to six times the official sales price despite US\$3.38bn spent on kerosene subsidies between January 2012 and July 2013 (Merrill et al. 2019). Subsidies and reforms meant to serve women as primary purchasers of kerosene have failed to benefit them because the subsidy is not targeted to poor households, or women, but to anyone who buys the fuel (Merrill et al. 2019). Moreover, unofficial price increments and persistent kerosene supply challenges means that poor people end up being overcharged by informal dealers who have a better link to them. This may be why the stoppage of the kerosene subsidy in 2016 attracted little or no protest.

\subsection{Historical overview: Fossil fuels and protests in Nigeria}

Popular protests over access to utilities and resources (including fossil fuels), regulated and/or owned by the government, have a long history in Nigeria dating back to the late nineteenth century (Okonkwo 1995; Adebayo 2020). Before the discovery of crude oil in commercial quantity in 1956, coal mining generated the main fossil fuel related protests in Nigeria. Nigeria has a proven coal reserve estimated at 54 million metric tons, most of which is found in Enugu in the southeastern part of the country (Adebayo 2020).

The Iva Valley massacre at the Enugu Colliery in 1949 is perhaps the most violent fossil fuel related protest in Nigeria's history. Colliery trade unions, dissatisfied with their working conditions, embarked on a strike in November 1949, after other attempts at collective bargaining had failed. Their decision to proceed with the strike annoyed the colonial superintendent of police, F. S. Philip. He ordered his men to open fire on the workers, killing at least 21 people and wounding 51 others (Jaja 1982; Brown 2003). This incident was one of a number of critical events that kindled the fire of nationalism which culminated in Nigerian independence in 1960.

Despite the significance of the Iva Valley massacre, fossil fuel related protests have been few and far between in Nigeria until the 1980s, by which point oil had overtaken coal as the prime energy source. Coal's share of total energy production in Nigeria declined from 98 per cent in 1958, to 1.6 per cent in 1966 as the government increasingly saw oil as a cheaper alternative (Adebayo 2020). 
There is no record of coal production at all during the Nigerian Civil War (19671970). The oil boom of the 1970s resulted in a massive inflow of new revenue for Nigeria, and irreversibly eroded the importance of coal as a resource worthy of government investment (Adebayo 2020). As petroleum increasingly became Nigeria's most important natural resource, any fluctuation in its prices or supply began to have a direct impact on the economy and, by extension, all aspects of national life. The most significant event that transformed the nature of fossil fuel related protests in Nigeria was the introduction of the World Bank and International Monetary Fund (IMF)-led structural adjustment programmes (SAPs) in 1986. The impact of deregulation and the adoption of market-driven pricing policies - which included high inflation, devaluation of the Naira, and unemployment - inflicted untold hardship on the Nigerian population. The inability of the state to meet the needs of the populace was met with increasing popular protests.

Table 1.1 chronicles attempts to remove or reduce the fuel subsidy by different Nigerian administrations and how this has been received by the citizens. A cursory look at the trajectory of struggles and their consequences in Nigeria suggests that in many instances struggles over fuel pricing and subsidies caused a shift of power in favour of the citizens when it came to energy provisioning policies. For instance, more than half of the citizen protests against fuel price rises led to either a downward review of the pump price of petrol or the introduction of social welfare palliatives or both (see Table 1.1). We return to this in subsequent sections.

\section{Table 1.1 Attempts to remove or reduce subsidy by different Nigerian administrations}

\begin{tabular}{|l|l|l|l|}
\hline Year & $\begin{array}{l}\text { President/Head of } \\
\text { State }\end{array}$ & $\begin{array}{l}\text { Change in price } \\
\text { [k=kobo; N=naira] }\end{array}$ & Remarks \\
\hline 1973 & Yakubu Gowon & $6 \mathrm{k}$ to $8.45 \mathrm{k}$ & $40.8 \%$ increase \\
\hline 1976 & Murtala Muhammed & $8.45 \mathrm{k}$ to $9 \mathrm{k}$ & $6.5 \%$ increase \\
\hline 1978 & Olusegun Obasanjo & $9 \mathrm{k}$ to $15.3 \mathrm{k}$ & $70 \%$ increase \\
\hline 1982 & Shehu Shagari & $15.3 \mathrm{k}$ to $20 \mathrm{k}$ & $30.7 \%$ increase \\
\hline 1986 & Ibrahim Babangida & $20 \mathrm{k}$ to $39.5 \mathrm{k}$ & $97.5 \%$ increase \\
\hline 1988 & Ibrahim Babangida & $39.5 \mathrm{k}$ to $42 \mathrm{k}$ & $6.3 \%$ increase \\
\hline 1989 & Ibrahim Babangida & $42 \mathrm{k}$ to $60 \mathrm{k}$ & $42.9 \%$ increase \\
\hline 1991 & Ibrahim Babangida & $60 \mathrm{k}$ to70k & $16.7 \%$ increase \\
\hline 1993 & Ernest Shonekan & $70 \mathrm{k}$ to N5 & $614.3 \%$ increase \\
\hline 1993 & Sani Abacha & N5 to N3.25k & $35 \%$ decrease \\
\hline 1994 & Sani Abacha & N3.25k to N15 & $361.5 \%$ increase \\
\hline 1994 & Sani Abacha & N15 to N11 & $26.67 \%$ decrease \\
\hline
\end{tabular}




\begin{tabular}{|c|c|c|c|}
\hline 1998 & $\begin{array}{l}\text { Abdulsalami } \\
\text { Abubakar }\end{array}$ & $\mathrm{N} 11$ to N25 & $127.3 \%$ increase \\
\hline 1999 & $\begin{array}{l}\text { Abdulsalami } \\
\text { Abubakar }\end{array}$ & N25 to N20 & $25 \%$ decrease \\
\hline 2000 & Olusegun Obasanjo & N20 to N30 & $50 \%$ increase \\
\hline 2000 & Olusegun Obasanjo & N30 to N22 & $\begin{array}{l}26.7 \% \text { decrease } \\
\text { after protests } 2\end{array}$ \\
\hline 2002 & Olusegun Obasanjo & N22 to N26 & $18.2 \%$ increase \\
\hline 2003 & Olusegun Obasanjo & N26 to N42 & $\begin{array}{l}61.5 \% \text { increase } \\
\text { (protests but no } \\
\text { decrease) }\end{array}$ \\
\hline 2004 & Olusegun Obasanjo & $\mathrm{N} 42$ to N50 & 19.1\% increase \\
\hline 2004 & Olusegun Obasanjo & N50 to N65 & $30 \%$ increase \\
\hline 2007 & Olusegun Obasanjo & N65 to N75 & $\begin{array}{l}15.4 \% \text { increase } \\
\text { (protests but no } \\
\text { decrease) }\end{array}$ \\
\hline 2007 & Umar Yar' Adua & Back to N65 & $\begin{array}{l}15.4 \% \text { decrease } \\
\text { after protests } \\
\text { against Obasanjo's } \\
\text { increase }\end{array}$ \\
\hline 2012 & Goodluck Jonathan & N65 to N141 & $116.92 \%$ increase \\
\hline 2012 & Goodluck Jonathan & N141 to N97 & $\begin{array}{l}31.2 \% \text { decrease } \\
\text { after protests }\end{array}$ \\
\hline 2015 & Goodluck Jonathan & N97 to N87 & $\begin{array}{l}10.31 \% \text { decrease } \\
\text { as election } \\
\text { approached }\end{array}$ \\
\hline 2016 & Muhammadu Buhari & N87 to N145 & $66.67 \%$ increase \\
\hline 2020 & Muhammadu Buhari & N145 to N124 & $\begin{array}{l}\text { 14.5\% decrease } \\
\text { (market forces }^{3} \text { ) }\end{array}$ \\
\hline 2020 & Muhammadu Buhari & N124 to N123 & $\begin{array}{l}0.81 \% \text { decrease } \\
\text { (market forces) }\end{array}$ \\
\hline 2020 & Muhammadu Buhari & $\begin{array}{l}\text { N123 to band of } \\
\text { N140 - N145 }\end{array}$ & Market forces \\
\hline 2020 & Muhammadu Buhari & $\begin{array}{l}\text { Band of N140 - } \\
\text { N145 to band of } \\
\text { N145 - N148 }\end{array}$ & Market forces \\
\hline 2020 & Muhammadu Buhari & $\begin{array}{l}\text { Band of } 145-148 \text { to } \\
\text { price cap of N151 }\end{array}$ & orces \\
\hline
\end{tabular}

Source: Authors' compilation from multiple sources

2 'Price adjustments' often occurred by the pump price of petrol going up, attracting protests, then the government responding by reducing the increase by a fraction, but not reversing it totally. In effect, the new price was still higher than the pre-increase price.

3 What we have referred to here as 'market forces' is a regime of partial regulation. The Nigerian government sets the band or boundary within, and not beyond, which prices can increase or decrease. 
In the analysis in this paper, we give more attention to the 2007 and 2012 fuel protests than to others because our event catalogue shows that these were the most widespread, prolonged and violent fuel protest episodes in recent times. See tables in the Annexe for a detailed description of the 2007, 2012 and 2016 protest episodes.

The 2007 episode is of particular interest because the fuel hike was introduced by the outgoing government of Olusegun Obasanjo, which announced a reduction of state subsidy on petrol and kerosene pushing the prices from N65 to N75 per litre just six days before leaving office. It is also worth noting that the withdrawal came despite over N350bn being appropriated in the 2007 budget for the purposes of a pump price subsidy on petrol and kerosene (Simpson 2007). This was the sixth time Obasanjo had increased fuel prices since he became president in 1999 (see Table 1.1). Labour unions waited until after the inauguration of the incoming government of Umar Yar' Adua on 29 May 2007 to launch a protest, which began with a 48 hour-sit-at-home strike from Monday 4 June (BBC 2007). The union combined their anger against the subsidy withdrawal with what they termed as the 'sham elections' that established Yar'Adua as president. The protests crippled government operations, leading to a cancellation of international and domestic flights, while the streets remained empty and government workers were ejected from government offices by protesters (Eboh 2007). Eventually, the government agreed to reduce the fuel price to N70 per litre and promised not to raise fuel prices for a year. This is after what the government spokesperson Olusegun Adeniyi, termed as 'a personal intervention by President Yar'Adua who listened to all concerned parties', but which other actors saw as 'a strategic move on the ruling party, PDP [People's Democratic Party] to reduce the mounting tensions from the population that felt Yar'Adua was rigged in' (Akanle, Adebayo and Olorunlana 2014: 93).

The 2012 protests were triggered by a petrol price hike by the Goodluck Jonathan government from N65 to N141 per litre on 1 January 2012. The government's subsidy reduction represented one of the highest price increases so far, more than doubling the price of petrol (see Table 1.1). The protests began within 24 hours of the price rise. Street protests and demonstrations broke out in various parts of the country and in the diaspora in major cities around the world. It should be noted that these were spontaneous eruptions which subsequently received labour union support from 9 January 2012 when the Nigeria Labour Congress (NLC) announced their planned strikes and protests, and then eventually became the protestors' representative in engaging in dialogue with government. Following these protests, the government, in February 2012, inaugurated the Subsidy Reinvestment and Empowerment Programme (SURE$P$ ), with the mandate to utilise subsidy funds to provide basic amenities. SURE-P was set up partly with the funds saved from partial reversal of subsidy. The protests also prompted the government to reduce the price of fuel to N97 per litre 
and galvanised the House of Representatives to set up the Farouk Lawan Committee to investigate implementation of the subsidy regime and expose corruption (Adetola 2015).

While not ignoring other protest episodes, we paid particular attention to the 2012 episode in this study for evidence of whether or not fuel protests lead to policy outcomes and the nature of those outcomes. 


\section{Methodology}

The overarching aim of this study was to investigate the conditions under which struggles over energy access in fragile and conflict-affected settings empowered the citizens to hold public authorities to account. A methodology that gave primacy to a multiplicity of views and actors was adopted: citizens who might have participated in or witnessed energy-related protests; activists, unions and organisations that might have planned or supported the protests; and government officials who might have had input into government response to the protests, were all included in the analysis.

From data from these actors and available documents, we investigated energy use in everyday life, conducted a political economy analysis of energy policies and protests, and studied energy struggles with a view to understanding their impact on empowerment and accountability in Nigeria. The term 'energy' is an inclusive notion for many products or services. However, the focus of this study is on fossil fuels: premium motor spirit (or petrol), diesel, kerosene, and cooking gas. These are the fuels over which there have been struggles for access (physical access and affordability) in Nigeria and the other study countries (Mozambique and Pakistan) for many years.

\subsection{Methods}

A comparative multi-methods design, which combined qualitative data and secondary data, was adopted. The qualitative methods were key informant interviews (KIIs) and focus group discussions (FGDs); and the secondary data was curated from newspapers for the purpose of events cataloguing. Through an events catalogue, we developed a database of fuel protest episodes and their severity.

The FGDs focused on citizens' energy needs, participation in protests, and views on government handling of energy issues. Some KIls focused on the views of government officials regarding the government's subsidy decision making, the subsidy process and government response to protests, while other KIls focused on the views of labour unions and activists regarding motivations for, and efficacy of, protests. While the KIls were conducted in Abuja and Lagos, the FGDs were conducted in Lagos (the epicentre of most of the protests).

Newspaper reports of fuel protest episodes constituted the main secondary source of data. These reports were used to create an events catalogue which enabled us to see not only the frequency of the protests, but the connection between episodes as well as the intensity of the protests. The consistency of the justifications for, and the means and consequences of the protests also became 
clearer as we analysed the events catalogue in depth. We developed a simple matrix to calculate the intensity of selected protests held in the ten years from 2007-2017, as a first step towards understanding why some protests escalate and others do not. This is described below:

- Actors: These were the individuals and organisations that might have an interest in the protests or in energy matters in general. We identified five categories of actors: organised labour and civil society organisations (CSOs), informal sector businesses, prominent individuals and politicians, external actors (such as the World Bank), and ordinary citizens. The actor score for a protest was determined by the number of actor classes or groups that took part in it. The lowest score was 1 , the highest 5 . Where for instance only organised labour protested, the protest got 1 as an actor score because labour constituted only one actor group. Where ordinary citizens joined labour, that made the actor score 2.

- Actions: What actions did the actors carry out? We identified three categories of actions: Talk/negotiate/write press release(s) offline or online; march/ protest; riot/disrupt/barricade. The action score for a protest was determined by the number of actions recorded. The lowest was 1 , the highest 3 .

- Duration: How long did a protest last? We had five categories and scores: less than a week ( 1 point), about a week ( 2 points), about two weeks ( 3 points), between two to four weeks (4 points), more than 4 weeks (5 points).

- Spread: How widespread was a protest? The spread score of a protest was based on the number of geo-political zones it covered. Nigeria has six such zones and a Federal Capital, Abuja. The lowest spread score was 1 (that is, happening in only one zone) and the highest 7 (that is in all zones and Abuja).

- Impact: What was the outcome of the protest? We identified four possible outcomes. No impact $=0$ point, government issues palliatives $=1$ point, government reduces fuel price $=2$ points, government combines palliatives with price reduction $=3$ points.

\subsection{Sampling}

Stratified and convenience sampling were combined in selecting discussants for the FGDs. Thus, discussants were selected from low-income and middleincome $^{4}$ neighbourhoods because energy issues are largely economic issues.

4 In determining income levels, we first considered the general socio-economic profiles of a neighbourhood. However, because in Lagos, people of different income levels live together in the same neighbourhoods, we had to apply a screener to help to sort discussants according to income levels. Type of occupation was the major screener in this case. Daily wage earners, cleaners, taxi and bus 
Attempts to have corresponding FGDs among high-income earners in other neighbourhoods did not succeed as they were largely unwilling to be involved in the research. Table 2.1 summarises the locations and number of participants per group.

\section{Table 2.1 Details of focus group discussions}

\begin{tabular}{|l|l|l|l|}
\hline Income level & Location & $\begin{array}{l}\text { Number of } \\
\text { discussants }\end{array}$ & Age range \\
\hline $\begin{array}{l}\text { Middle- } \\
\text { income }\end{array}$ & Shomolu & 9 & $40 s-50 s$ \\
\hline $\begin{array}{l}\text { Middle- } \\
\text { income }\end{array}$ & Bariga & 8 & $40 s-50 s$ \\
\hline $\begin{array}{l}\text { Middle- } \\
\text { Income }\end{array}$ & Ikeja 1 & 8 & Mid 20s-early 30s \\
\hline $\begin{array}{l}\text { Middle- } \\
\text { income }\end{array}$ & Ikeja 2 & 8 & $40 s-50 s$ \\
\hline Low-income & Maya & 12 & $30 s-50 s$ \\
\hline Low-income & Isiwu & 11 & $40 s-50 s$ \\
\hline Low-income & Imota & 11 & $40 s-50 s$ \\
\hline Low-Income & Adamo & 12 & $30 s-60 s$ \\
\hline Low-income & Ikeja 3 & 9 & $40 s-50 s$ \\
\hline
\end{tabular}

Source: Authors' own

Male and female discussants were included in each group in order to make the gathering as gender equitable and representative as possible. In Lagos State, in contrast with northern Nigeria where Islamic norms prevail, it is not usual to separate male and female citizens in public gatherings, so any attempt to have had separate groups might have created unease on the part of some discussants. Efforts were made to have a spread of occupations included within each FGD, as well as ensuring that no more than one discussant was recruited from each house or office, to ensure the groups were as diverse as possible. Research assistants, being familiar with the city, worked with a screener and guidelines to invite discussants. 
The selection of respondents for the Klls was purposive. Organisations contacted were the NLC, Spaces for Change, Centre for Democracy and Development, Joint Action Front (JAF), Nigeria Labour and Civil Society Coalition, Facility for Oil Sector Transformation Project (FOSTER), and BudgIT Nigeria. Among activists and labour unions, only members of the executive or managerial staff were interviewed. These people were chosen because of the leading role they had played in mobilising citizens for fuel-related protests in the past. In total, we conducted interviews with eleven activists and labour leaders. Similarly, government officials in departments or parastatals connected to fossil fuel issues were also purposively selected. The departments included the Nigeria National Petroleum Corporation (NNPC), Petroleum Trust Development Fund (PTDF), the National Assembly, and the Presidency. Interviews were conducted with seven government officials.

Sample selection for the events catalogue began with a search for the dates of significant fuel protests since 2000. We identified three major episodes: 2007, 2012 and 2016. This was followed by a selection of newspapers across geopolitical zones. Care was taken to include pro-government, anti-government and non-committal newspapers in the selection. Five newspapers were selected: This Day, Daily Trust, The Nation, The Guardian and Premium Times. We conducted both an online and hardcopy search of these newspapers, paying attention to their reports of fuel protest events, the main facts about the events (including date, location, description of the events, number, and identity of actors), explanations of the events (such as actors' grievances and claims), effects of the events, and sources of the reports. We expanded the search to international newspapers as well using the search descriptors: 'fuel protests', 'fuel scarcity', and 'fuel subsidy removal'. The search yielded 129 reports of fuel protests between 2007-2017. The same search descriptors guided the search for memes and other popular cultural expressions such as songs, cartoons and others. In all, we collected 45 such expressions.

\subsection{Data collection procedure}

The data collection process was sequential, beginning with the events catalogue, followed by the FGDs, which were in turn followed by the KIls. The claims made during the FGDs were reflected in the KII questions posed to activists, labour leaders, and government officials. Thus, the events catalogue fed into the FGDs which fed into the KIIs.

In conducting the KIls and FGDs, we were guided by the elaborate protocols developed at the beginning of the research. With the permission of interviewees and discussants, the KIls and FGDs were recorded in audio format for later transcription. The FGDs were collected by a three-person team, one of these was a note-taker while the other two took turns to keep the conversations going. 
Time spent on each discussion depended on how expressive the discussants were, but generally lasted between 45 minutes to a little over one hour. The FGDs were conducted between December 2019-February 2020.

\subsection{Validation of the research procedure}

The research procedure was validated at a stakeholder engagement meeting on 10 July 2019. Following a two-day research-design workshop, we hosted the key stakeholder engagement workshop with about 40 people invited from academia, government agencies, civil society and energy advocacy/activist groups, government agencies, oil producing communities, and the media. The purpose of the meeting was two-fold: one was to get input from this broad range of stakeholders on the research focus and procedure and tackle any foreseeable feasibility challenges; the other was to nurture a relationship that would be useful later at data collection and research uptake stages.

The research team presented the research to the stakeholders, highlighting its design, aim, methods and potential uses. The meeting engaged in a thorough critique of the research procedures, especially the instruments. Together, we generated the list of potential interviewees and the contacts of some of them. We also received input into mapping the FGD locations. Importantly, we received suggestions on how to disseminate the research findings and got buy-in from participants that they would use the findings and support the uptake.

\subsection{Ethics}

Utmost care was taken to ensure respect, safeguarding and the safety of all involved in the research. Informed consent was obtained before KIIs and FGDs were conducted and recorded. Transcribed data were fully anonymised and audio files were stored in a confidential folder to be destroyed later. Though our risk analysis showed that the KII and FGD locations in Nigeria had low risk with regards to researcher safety, care was taken to be risk conscious throughout the data collection process.

We paid attention to the question of copyright in the use of lyrics and memes. The Nigeria Copyright Act allows use of copyrighted materials (including lyrics) for research and non-profit purposes. We stayed within the limits of the Act in our use of the materials. 


\section{Fragility, social contract, and the escalation of energy struggles}

Why do struggles around energy have the potential to grow into significant episodes of contention in Nigeria? Is there a link between fragility and the observed major movements or struggles around fuel? To explore this, we hypothesised that fuel subsidies are an important part of the social contract and of social protection in less stable settings with weak elements of governance, and in resource-rich/energy exporting countries.

Despite being a major producer and exporter of crude oil, Nigeria is a net importer of finished petroleum products. The findings suggest that several factors explain why energy struggles grow into significant episodes of contention in Nigeria. These include: resource nationalism and value nationalism, labour unions' national and global reach, erosion of purchasing power, genuine and artificial ripple effects of tinkering with fuel prices, and a feeling of injustice and anger among citizens. What drives the energy struggles is the belief by ordinary Nigerians that they rarely benefit from the huge revenues generated from oil export, and that the sector remains poorly governed and beset by bribery and corruption. Below we discuss some of these factors, drawing from various data sources.

\subsection{Nigeria, fragility and fuel subsidies}

There is a strong belief among Nigerians that affordable fuel prices are a right, given Nigeria's huge oil reserves. Nigerians believe that any reform should lead to achieving this right, or at least should not diminish it. Conversations regarding fuel pricing are an important part of election campaigns and party politics. As such, fuel provisioning and affordability constitute one of the core elements of the social contract in Nigeria. One of our respondents noted: 'If you take subsidy out of the picture, to a very large extent a lot of citizens would believe that you have breached that social contract which they trusted you with when they voted you into power' (KII 10). The inability by the government to deliver on this, which leaves many poor people exposed to the negative effects of high fuel prices, is interpreted as failure to ensure security, deliver basic services, and an abuse of the social contract. The following comments in our discussions with FGD participants confirm this: 'The way the government is handling the fuel issue is wicked. Why are our refineries not working? Why are they importing fuel from refineries outside the country built by our leaders?' (FGD 04); 'The fuel subsidy being released by the government is a hoax because government officials steal this money' (FGD 01). 
Perceived mismanagement of the subsidy regime has incensed the public against attempts to remove it. It is perhaps more useful to see the politics of fuel subsidy removal in Nigeria from the perspective of contestations around the nature of the social contract, entitlement, and the moral economy. Central to the dissatisfaction with state handling of fuel subsidies are factors such as the exclusion of citizens from fuel policy formulations, insufficient communication of government policy direction, and widespread inherent opacity in the system. However, depending on the situation, those elements have manifested themselves even when the state was conceived as strong and stable.

\subsection{Escalation of fuel subsidy struggles into major episodes of contention in Nigeria}

Episodes of fuel-related protests in Nigeria are caused either by an increase in the prices or by a scarcity of fuel products, most especially, petrol. As shown in Table 1.1 (Section 1.3), while some of these protests escalated into major popular struggles, others remained moderate or almost invisible. Our event catalogue, covering ten years from 2007-2017, shows the unevenness in the intensity of the protests. In order to assess different levels of protest intensity, we came up with five different categories which we described earlier on in Section 2.1. The assessment yielded the results presented in Table 3.1.

\section{Table 3.1: Protest episodes: 2007 to 2017}

\begin{tabular}{|l|l|l|l|l|l|l|}
\hline Year & Actors & Action & Duration & Spread & Impact & $\begin{array}{l}\text { Intensity } \\
\text { score }\end{array}$ \\
\hline 2007 & 3 & 2 & 3 & 2 & 1 & 11 \\
\hline 2008 & 1 & 1 & 1 & 2 & 0 & 5 \\
\hline 2009 & 1 & 1 & 1 & 1 & 0 & 4 \\
\hline 2011 & 2 & 2 & 2 & 1 & 0 & 7 \\
\hline 2012 & 5 & 3 & 5 & 7 & 3 & 23 \\
\hline 2015 & 1 & 1 & 2 & 1 & 0 & 5 \\
\hline 2016 & 2 & 2 & 1 & 4 & 0 & 9 \\
\hline 2017 & 1 & 1 & 1 & 1 & 0 & 4 \\
\hline
\end{tabular}

Source: Authors' Events Catalogue

As described in Section 1.3, the 2007 and 2012 protest episodes were by far the most intense in recent history. These went on for many days and involved a wide array of actors, including ordinary citizens, civil society organisations, organised labour, and opposition politicians. Of all the episodes in our catalogue, the 2012 event was the only one that recorded deaths. Within one week of the protest, eleven protesters had been reportedly killed. The number grew to 15 by the 
following week. The majority were killed by security agents, while a few others died in accidents during the protest. For instance, a motorcyclist and his passenger, struggling to escape from being stopped by the protesters, crashed and died (Popoola et al. 2012).

It is also important to note that fuel-related protests have been recurrent. In between the spikes are usually small rumbles that keep the subject of fuel access in the public consciousness. So, discussions of fuel-related problems never really disappear from the public radar.

It could also be said that the intensity of protests connects with the overall perception of government. The 2009 protest was the mildest, followed by the 2008 protest. This mildness could be connected with the general perception of President Yar'Adua as a pro-people president. A few hours before handing over power to Yar'Adua in 2007, President Obasanjo increased the price of fuel from N65 to N75, but on assumption of office, President Yar'Adua reversed that decision, thus endearing himself to the people. It seemed that goodwill lasted throughout his three-year tenure which ended with his death in 2010.

This leads us to the question, why do some fuel-subsidy struggles escalate into major episodes of contention in Nigeria? Answering this question requires an understanding of Nigeria's oil economy and politics, and how decades of corruption, mismanagement and neglect of vital infrastructure and services have produced a lethal mix of dysfunctional politics and governance. For instance, Nigeria has four refineries, but poor maintenance and outright sabotage has ensured that they operate far below installed capacities. Rice (2012) suggests that even in 'good' years, the refineries have been able to satisfy at most 25 per cent of domestic consumption. The government has had to provide for the shortfall in domestic refining by importing fuel, which is sold to the public at controlled prices. The fuel subsidies have the aim of alleviating poverty and maintaining price stability. It has, however, been argued that they contribute, significantly, to the deterioration of the government balance of payments (Galiana and Sopinka 2015; IMF 2019a).

Petroleum exports provide significant revenue for Nigeria. However, the revenues hardly translate into observable benefits for citizens, particularly the poor. Instead, a large proportion is siphoned off by the ruling elites through an intricate web of corruption (Nwachukwu and Chike 2011; Social Action 2012; Osunmuyiwa and Kalfagianni 2017). This web of corruption has eroded the confidence and trust of many Nigerians who believe the subsidy regime hardly benefits the poor, underscoring the basis of the breakdown of social contract between the citizens and the state. One respondent explained: 
and over for years that they are the ones benefitting and they don't know how to check if they are benefitting or not...so the money we've spent on subsidy are [sic] lost, such that the government claim ...that they are using it to help the poor people, and barely any poor person have benefitted from it. (KII 12).

In this context-of the government's inability to meet the daily basic needs of its citizens - citizens are left with no option but to provide for themselves these basic elements of everyday existence. Affordable fuel is one of the main direct benefits that Nigerian citizens, the majority of whom live on less than a dollar a day, can get from their government. Due to the fact that subsidised fuel has a direct impact on citizens, and is arguably part of the everyday coping mechanism, attempts at removing the fuel subsidy inevitably translate into an emotionally charged subject with a history of contention and protests. A key informant explained it this way:

It has become basically a cultural and political issue where Nigerians believe since we have petroleum and as government does not give us anything other than cheap fuel. Let us hold them to account on the basis that citizens want cheap fuel and therefore government must not go against the wish of the people and raise the price of fuel. Emotionally, citizens feel the only thing they benefit from government is petrol. (KII 09).

Before the Goodluck Jonathan administration attempted to reduce the fuel subsidy in 2012, there were claims of widespread corruption and mismanagement in the oil sector (Okonjo-Iweala 2018). The government admitted that a powerful clique had taken advantage of the fuel subsidy scheme. In what appeared as a manifestation of state powerlessness, the government showed an inclination towards removing the fuel subsidy rather than dealing with the so-called clique. When the government suddenly announced a reduction of the subsidy, which immediately increased the price of fuel from N65 to N141 (an over 100 per cent increase) on 1 January 2012, street protests erupted in various parts of the country. The President was accused of unilaterally imposing the hike without consultation, in a clandestine attempt to enrich corrupt officials and marketers (Gbadeyan undated). The labour unions joined the protests and mobilised support from Nigerians in the diaspora and the international labour movement. The mobilisation of international support energised the public and gave them hope that the protests would succeed.

From the events catalogue analysis, one major pointer to the escalation of protest episodes is the breadth of the coalition of actors. The broader the coalition, the more likely the escalation of the protest episode. However, the breadth of coalition is a function of the nature of the cause of the contention. Nationwide issues such as fuel price increase attract more actors than localised 
fuel scarcity in a state (which was behind the 2015 protests) or the working conditions of tanker drivers (which led to the 2008 protests in some parts of the country).

In the case of the 2012 episode, existing networks of experienced protesters, labour unionists, religious leaders, and popular opposition politicians provided ready leadership, organisational, and symbolic resources, which energised the movement. Besides non-material incentives, the organisers of the protests provided the protesters with food and water, which served as inducements to join and remain in the protests. An important part of the protests was the use of popular media including music, arts, and cartoons. In the section that follows, we present a summary of the role played by these media in sustaining the protests.

\subsubsection{Popular culture and the energy protests}

It is difficult to imagine any protest without expressions of popular culture, especially songs, drama, and drawings. As a result, a large body of studies has emerged on the role of popular media in protests. Mobilising people for 'action' (van Blommestein and Hope 2012; Olorunyomi 2013); articulating the demands of protesters (Valassopoulos and Mostafa 2014); and energising protesters so that they can maintain their vigour (Eesuola 2015); are some of the functions of popular media in protests. In this section, we summarise the three major roles that popular media played in the fuel protests which are the focus of this study.

In this study, we found that popular culture served as the memory bank of the national and global events that were connected to fuel crises. Van Blommestein and Hope (2012) see this role as illustrating history and generating nostalgia. In Lagbaja's Suuru Lere (Motherlan' Music 2000), for instance, he chronicles the history of Nigeria from amalgamation in 1914 to the fuel crisis of 2000. Through three layers of 'text': song, acting and dance, as well as cartoons and newspaper headlines as moving backdrops, he highlights what stood out in each of the leaders Nigeria had had up to that point. He then focuses broadly on the contemporary events in Nigeria of that time: unstable democracy and the lurking presence of the military who had just handed over power, rough fights in the National Assembly, poverty and a struggling economy, erratic power supply, and the tension around fuel prices.

The lyrics, codeswitching between Yoruba and Nigerian Pidgin, are admonitions for Nigerians to protect their newly-obtained democracy through patience and cooperation. However, in an intricate artistic balancing, the animations illustrating Lagbaja's lyrics do not preach patience or protection of democracy; rather, they focus predominantly on the daily struggles of the masses including power failure, poor sales, homelessness and destitution, and contention around fuel prices. The struggle between the NLC and the federal government over the latter's attempt to increase the price per litre of petrol from N11 to N30, and the 
resolution of that contention (a reduction of the price to N22 per litre), are captured in the animated backdrop. This is not to suggest that popular media functions merely as a passive recording of historical events. Rather, it is an active processor of those events with a view to connecting them with the present. Lagbaja, for instance, combines carefully selected parts of the past to demonstrate a message about the present.

The second function of popular culture within these protest episodes was to present the current problems in a way that compelled attention and evoked support for the protests. This second function responds to the question of just how bad the situation is, and it usually invites people to think deeply about the problem or the reason for the protests (Eesuola 2015). Lagbaja in Suuru Lere (2000); Aduke in Hear the Voice against Subsidy Removal (2012), Flavour in Nigeria Ebezina (2012), and Tha Suspect in Subsidy (2012, CAPitalHill Music), among others, depict the deplorable conditions of fuel supply and access. Flavour opens his video with a guard dog watching over a can of petrol, suggesting how precious and expensive petrol has become, Aduke and Tha Suspect, like Lagbaja, show endless and chaotic queues at filling stations. Traditional (non-animated) cartoons have also fulfilled this second function. Segun Awosiyan's 'What It Seems Like' depicts subsidy removal as a huge sledgehammer (the size of an oil barrel) being unleashed on a figure representing the masses who is already blindfolded and chained by poverty. Yet, the defiantly raised hands and head of the masses suggest they remain unbroken by the situation.

There are numerous online memes depicting the extent of the problem of fuel scarcity in Nigeria. One striking example shows a young man sleeping in his room with his can of petrol and a generator chained around his waist with a hefty padlock. The preciousness of fuel is emphasised here by the fact that the fuel is more important than his phone which is left on his back unprotected. Not only are the can and the generator chained, his hands are on them to further secure them as he takes a nap. It is important to note that the generator is not as precious as the contents of its tank: the fuel.

Another popular meme shows a dialogue between the then Minister of Petroleum Resources and a young man. The Minister was asking to see the man's fuel gauge, as a measure of his wealth/manliness before acceding to his request to marry her daughter. This emphasises the telling impact of fuel price increase on basic interpersonal relationships.

Yet another meme depicts a young man in military camouflage sleeping with his legs up in his car with the inscription, 'When there is no more fuel to continue the journey'. Beyond the literal sense, this signifies how subsidy removal and fuel price increases affected (or affects) 'journeys' - ambitions, career and personal progress generally. 
Together, the memes, cartoons and music videos present an unpleasant atmosphere of fuel scarcity and its devastating effects on the poor. They are both descriptive - stating what was going on; and 'prophetic', alerting people to the difficulties that awaited their careers, relationships, and future if the fuel price increase was not reversed.

The third function of popular culture in these protests was a reinterpretation or reimagining of the fuel crisis. Valassopoulos and Mostafa (2014) identified this function of reinterpreting and re-imagining among popular artists in Egypt as they gathered in the Tahrir Square during the Egyptian revolution in 2011. The reimagining led the protesters to see the link between the current protest and older ones, just as they shaped emerging desires and aspirations. In Nigeria, the protest media contents and artists reinterpreted and reimagined the problem as being beyond just fuel. 'Discussions' often connected the fuel crises with wider issues including corruption, misappropriation of funds, poverty, and violence. In her Hear the Voice against Subsidy Removal (2012), Aduke sings of the inability of the 'common man' to afford fuel and thus their resort to wailing about fuel, food, water, light and shelter.

Through their songs, artists depict an already trying environment for the masses, which then allows them to make the point that any removal or reduction of subsidy would be an excruciating blow to Nigerian people. It was understandable, therefore, that the 2012 protesters, for instance, quickly moved beyond asking for a restoration of the fuel subsidy into demanding better governance, an end to corruption, and palliatives from economic hardship.

It is difficult to specifically estimate the contribution of popular culture to the protests against fuel hikes. However, it is clear that it performed significant functions of historically contextualising the protests, and helping protesters to a better understanding of the enormity of national problems both in terms of their weight and nature. In doing this, popular culture, at least, indirectly contributed to the sustenance of the protests in the hope for a better deal for the people.

\subsection{Understanding attitudes to fuel subsidies in Nigeria}

To understand the immense opposition to fuel subsidy withdrawals and/or reforms, it is important to underscore the fact that price increases reduce citizens' purchasing power and income - which may already have been small rendering them almost worthless, and resulting in inflation. Inflation affects micro and small businesses, and engenders general restlessness among the citizens. Most discussants had unpleasant experiences to share about how fuel price increases had affected them and their families on many fronts. One such 
discussant stated how increases had led to absenteeism, and even dropout of their children from school:

It affected children and their education. Then if you had [a] child attending the secondary school in Ikorodu, if you give your child N300, it should be enough for transport and their school meal but when such a child gets to the garage and they say the transport fare is N500, it means he has to take N1,000 to school. If he goes today, would he be able to attend school tomorrow? And the child has siblings too. It is quite difficult to be giving a thousand Naira daily to a child. One may have to tell the child to drop out of school. (FGD 02).

Such lamentations as this were echoed across all of the FGDs. The impact of fuel price increases on businesses, especially small-scale businesses, was underscored as well:

Someone who want[s] to go to market and was given N2000 and such a person has already spent N500 or N700 as transport fare, (food is compulsory) and the children have not eaten at home. Will one return to the market the next day? One would be forced to stay at home, so that is my response. (FGD 01)

Someone who repairs generator[s] and is called for some repairs. To go from this place to Ibafo would be quite expensive. If I borrow 1000 Naira to go, it will not get me there. (FGD 01)

The ripple effects of fuel increases on the whole economy, and particularly the livelihoods of the poor (increases in the cost of transport and food), contribute to provoking the people to collective action. People are convinced that through mass action, they can demand official attention. As one participant told us, '...you will see that those people became voices, very visible voices...' (KII 10). To explain why energy struggles, tend to explode into major episodes of contention in Nigeria, another stated that 'by increasing fuel price, government automatically mobilises the people' (KII 05). A narration from one of our respondents, who has worked in a Nigerian civil society organisation, explains how anger and frustration from unpredictable pricing for a commodity that the masses depend on can embolden mass action:

Let's paint a scenario of you going to work in the morning and you boarded a bus and you had an idea of the transport fare. So, you tucked a 1000 Naira note into your pocket, the worst case scenario you thought of is that you're going to have change like 300 Naira [sic]. On your way back from work, you are informed that the transport fare has increased to 1,500 Naira. That information alone 
turns off a knob in your head and you get angry. Then angrier people begin to raise their voices to express their anger. You know that one voice raised emboldens others who are just nursing their anger internally because of a feeling of oppression, injustice, and a feeling of something not being right. (KII 01).

... citizens protest because they have this feeling that they come from an oil producing country, so they should have access to cheap fuels and I argued that it is more than that because when we feel cheated there is a tendency to protest when we see that we are not been treated well and that is different from the feeling of 'I need to access cheap fuel'. (KII 01)

In other words, while it may appear that fuel pricing is an emotive issue, it is also about governance and how the government communicates with its citizens. The majority of the interviewees decried a lack of structured communication channels to explain the reforms that sometimes lead to subsidy withdrawal and concomitant prices hikes. Citizens lack formal channels for engagement (KII 09). The following quotes from our KIls and FGDs are illustrative:

One of the reason [sic] they take to the street is that they do not believe that the available communication channel is adequate enough to get their grievances across to policy makers, on the other hand the policy makers are not doing enough to communicate the impact of the benefit of subsidy removal sufficiently to the citizen, and even when they communicate these benefits sufficiently, there is still that element of trust deficit between the citizen and the government. (KII 10).

...we do not have access to the government and government is in charge. (FGD 03).

The suddenness of many fuel price increases, as well as the absence of an avenue for citizen engagement and dialogue are some of the key reasons that fuel protests erupt and escalate.

\subsection{Political and civic space and popular engagement with fuel price}

Evidence suggests that there are few formal effective institutions in Nigeria through which citizens' interests can be processed or articulated for redress. ${ }^{5}$

5 In Nigeria, the Federal Competition and Consumer Protection Commission is the only formal institution through which citizens' interests on issues such as fuel price can be addressed. 
The political parties, which should articulate their members' interests, and channel members' demands through to the government for effective resolution, have long abandoned such activities. Trade unions like the NLC, and nongovernmental organisations (NGOs), provide the government with identifiable actors or leaders to reach out to for negotiation when largely unorganised citizens take over the streets in protest. Such occasions enable the labour unions to demand concessions from the government. Beyond such periods of unrest, there is little space for popular engagement with fuel price.

During the Obasanjo civilian government, the international price of fuel became uncontrollable, and the result was shortages of the product all over the country, and lots of protest. Obasanjo decided to set up a committee that metamorphosed into the Petroleum Products Pricing and Regulatory Agency (PPPRA) in 2003. The PPPRA was made up of several stakeholders and groups like the labour unions, Major Oil Marketers Association, Road Transport Workers Association, Road Transport Workers Union, etc. The PPPRA Board has about 26 interest groups drawn from across the agency. With the interest groups there was more engagement than before. However, sometimes fuel prices were not discussed at the PPPRA Board meetings before they were imposed. Most times, government just decided on price and give public announcement. The challenge had always been not carrying people along. (KII 09).

It should be noted that any opportunity for public engagement is crippled when policy deliberations regarding fuel price are rushed, as is often the case. As a result, there is no formal political or civic space for popular engagement with negotiating fuel prices or other policies. Thus, following subsidy removal, citizens along with the labour unions and NGOs often seize the public space to vent their anger. It is instructive that no politicisation or restriction has prevented Nigerians from taking to the streets whenever they choose. Under both democratic and authoritarian regimes, Nigerians have taken over public spaces in major cities across the country in protest and contestation to express their opposition to fuel subsidy removal.

It appears that the level of accountability the citizens or protesters can demand from a government is directly proportional to the leverage they exact on that government. If they do not have any leverage on a government, citizens will have limited influence over the government and will thus achieve little with protests. As a respondent explained: 'Protest could once a while become episodic, but beyond that, it achieves extremely little in terms of engendering proper transparency and accountability framework, because those actually protesting have limited leverage over the government' (KII 10). 
Actors like the labour unions are able to exert pressure on the government and are in a position to actually promote the institutionalisation of accountability. However, accountability and transparency in government may not be a priority for the unions. In effect, the unions fail to use their leverage to compel more accountability and transparency in government. Key informant interviews suggested that union leaders do not see a direct negative impact on their salary and job, since 'the government can continue to be opaque or unaccountable, I mean they could care less' (KII 10). FGD participants hinted at this by accusing labour unions of using citizens to achieve a salary increase for government employees, perhaps to maintain their power and relevance, rather than pursuing a broad-based agenda that would improve the livelihood of every Nigerian.

\subsection{Gender roles and participation in energy struggles}

Protests around energy reveal an interesting variety of gender roles among the various actors. While traditional gendered expectations played out in some areas, unconventional roles played out in others. This can be traced along expressions of energy needs, organising for protests, participation in protests, and in negotiating with government.

Our analysis of women's and men's energy needs as expressed during the FGDs indicated a blurring of the line between what men found important compared to what women found important (Skutsch 2005; Kooijman-van Dijk 2020). Whereas everyone agreed that petrol was important, men seemed to show as much concern about cooking gas as women did. A male discussant opined:

If there is no petrol, we cannot work. But if there is no gas, our wives cannot cook for us. They use kerosene but that has become expensive... We use the money we make from going to work to buy gas. (Male, FGD 05)

This is contrary to expectations that depict men as least concerned about energy matters related to food and cooking for the household. Furthermore, both male and female respondents ranked petrol as important for transport and work purposes. This was particularly so among men who operated factory machines and women who operated food grinding machines at home or in their shops. A key marker of men's familiarity with cooking gas issues was their ability to quote the changing prices of gas, quotes that agreed with those of women most of the time. We found this familiarity with prices and ranking of gas in importance next to petrol among both low-income and middle-income men. 
Interestingly, however, there was disparity in the type of adjustment made by men and women. While men talked a lot about having to cut down on how much they gave their wives as upkeep for the family, or to stay nights at work to cut down on the amount spent on transportation, women talked of adjusting the quality and mode of preparing food for the family. A female discussant said:

I hardly cook at home again. We buy food to eat. It is cheaper that way. In fact, I will soon leave as I have 5 children to feed and time is going, I need to go work for money. (Female, FGD, 04)

And another said: 'Before I usually had a huge amount of provisions like Bournvita, Cabin biscuits and so on at home, I had to stop things like this during that period' (Female, FGD, 03).

Mobilising and organising people for participation in the protests was done almost exclusively by men. Among our discussants and interviewees, Ayo Obe and Joe Okei-Odumakin were about the only prominent women they could remember as mobilisers or organisers of the protests. Ms Obe is a Lagos-based lawyer and a former Head of Nigeria's Civil Liberties Organisation, Ms OkeiOdumakin is a human rights activist and President of Women Arise for Change. The list of protest leaders jointly generated during the research inception meeting resulted in the names of about fifteen mobilisers, eleven of whom were men.

Participation has been, however, more inclusive than mobilising and organising, albeit in a gendered way. An overwhelming majority of street protestors have been men, with women participating by obeying stay-at-home orders from the labour unions. An exception is the 2012 major protests in which thousands of housewives took over the streets of the ancient city of Daura, Katsina state, in a long procession on the first day of protests (Lakemfa 2015: 132). However, our discussants could not name one woman amongst the key speakers that addressed the crowds in Lagos in 2012. The discussants also recalled that the entertainers that kept the protesters occupied in Lagos were also male.

Unwillingness to participate in future protests was strongly expressed by both men and women. The same reasons - distrust of protest organisers, fear of repression, protest fatigue, and the inability of protests to produce expected outcomes - were given by both men and women.

Finally, more men than women were involved in the negotiation between labour unions and the government as the protests moved towards resolution. The Minister of Petroleum Resources and the Minister of Finance in 2012 were both women and were actively involved in the fuel subsidy discussions as government representatives (Okonjo-Iweala 2018). However, only two women were involved in the team of about twelve that represented the citizens and the labour unions. The extent to which these 'representatives' presented the particular concerns of women remains doubtful. Not only this, most of the over 60 organisations that 
have been involved in organising fuel protests since 2007 have been headed by men.

A gender analysis of the protests around energy access in Nigeria suggests a changing trend in men's energy priorities, and thus suggests the need to be sensitive to relying on existing literature on the issue. More recent experiences of protests in Nigeria, Benin Republic, Togo, Senegal and Sudan also challenge the prevailing assumptions about the masculinisation of the civic space when it comes to protest planning, actual protests, and negotiation with governments. As a recent study showed, women's movements and women-led movements are rising to challenge the status quo and injustice and are contributing to the reimagination of democracy (Aina et al. 2019). Women are no longer hidden, and their contribution to fuel protests in Nigeria may need a more detailed investigation beyond this paper.

In conclusion, the anti-subsidy removal protests embody much more than a desire by the Nigerian populace to take direct and increasing control of economic activity in the oil sector, or what is commonly referred to as 'resource nationalism'. It involves a charge against elite corruption and violation of national values. For Nigerian protesters, there is a continuity between bad leadership, corruption, inefficiency, elite deception, and price deregulation in the energy sector. Fuel subsidy removal becomes a veritable opportunity to protest unfair hikes in prices, and corruption, the underbelly of the deregulation of prices. In the people's minds, there is no separation between 'resource nationalism' and 'values nationalism'. Citizens often resort to street protests because there are few or no formal political or civic spaces for popular engagement with fuel price or other policies. Thus, following subsidy removal, citizens along with the labour unions and NGOs often seize the public space to demonstrate their anger. 


\section{Popular struggles, rights to energy provisioning, and accountability}

This section assesses how popular energy struggles might have strengthened accountability in Nigeria. As shown in Table 3.1, the 2007 and 2012 protest episodes were the most impactful during the period between 2007 and 2017. Both these episodes spread across most of Nigeria's geo-political zones, had the highest diversity of actors, persisted for the longest duration, and resulted in the government reducing the fuel price. Generally, episodes that led to a reversal of government policy or resulted in some other palliative had a number of actors involved (see Tables 1.1 and 3.1). Where actors were fewer than 3, the spread seemed to be narrower and the duration brief. Such protests also seem to have little impact.

\subsection{The 2012 protest dynamics}

The 2012 mass protests over fuel subsidy withdrawal proved that protest episodes that persist often diffuse beyond urban centres and gain national and international attention. When these protests exact responses from government, this may be seen as a form of accountability. Accountability requires that struggles have 'teeth', or 'holding power' of sufficient magnitude to compete for governmental action. The protests need to demonstrate the capacity to incur significant socioeconomic costs or disruption to major centres, and to attract widespread public support or important political champions.

The 2012 new year 'fuel price hike aroused popular outrage' resulting in mass protests across Nigeria (Social Action 2012). Over a week of nationwide mass actions led to a virtual shutdown of the economy in January 2012. Even in the rather conservative northern Nigeria, protesters took the ancient city of Kano by storm (Adetola 2015). Within 24 hours of the announcement of the new fuel prices on Sunday 1 January 2012, Kano youths started mass mobilisation and brought parts of the ancient city under their control.

In Lagos, Gani Fawehinmi Park (named after the renowned human rights lawyer and activist) was the headquarters of the protest where intellectuals, politicians, human right lawyers, activists, party leaders, pastors, imams, and popular musicians gathered. A year after the protests, the National Mirror, a national newspaper, characterised the magnitude of the protests thus:

Nigerians from across the divide, putting aside religious and ethnic differences almost brought the government of President Goodluck Jonathan to its knees, when they embarked on [a] series of protests 
to resist the arbitrary increment in the pump price of Premium Motor Spirit (PMS) otherwise known as petrol from N65 to N141.

(Melaye 2013: 14)

The labour movement joined the fray on Monday 9 January 2012. The House of Representatives weighed in on the eve of the planned protest by passing a resolution calling on the government to rescind its fuel price increase decision. The executive branch of government ignored the resolution. On the first day of protests, thousands of housewives in Katsina State 'marched through the streets of the ancient city of Daura in a long procession' (Lakemfa 2015: 132). Markets and other business premises were shut down in Katsina State as a result of the street protests and rallies. The Katsina State chapter of the Nigeria Bar Association urged the National Assembly to impeach President Jonathan should he refuse to rescind the decision on the fuel price hike.

'Spill-over' protests by Nigerians in the diaspora were held in major cities around the world. In the UK, Canada, USA, Ghana, South Africa and other countries, Nigerians took to the streets to register their anger at a policy that ultimately imposed more hardship on their compatriots at home (Social Action 2012). At home, the labour unions internationalised the protest, sending a message to Nigerians to protest in front of the World Bank premises in Washington DC. The labour unions alleged that the World Bank and the IMF engineered the fuel price increase (Lakemfa 2015). Thus, it would appear that in the case of Nigeria, protests did enable citizens to engage with the government and somewhat achieve 'voice'. Research participants noted that the protests opened up the democratic space for citizens to engage with the government.

The struggle has always sent a message of caution to the government and often forced a compromise between an unpopular policy and the demands of the people often leading to negotiations of social services which may come as palliatives. (KII 07)

...you will see that those people became voices, very visible voices... (KII 10)

The question of protests exacting a response from government in Nigeria has been documented in studies. For instance, Aina et al. (2019) documented the impact of the Bring Back Our Girls (\#BBOG) movement. Protests that trigger government response often have to be sustained and contain the potential to affect the government's image.

The 2007 and 2012 protests in Nigeria achieved their objectives partly because they were led by strong labour union leaders and eminent personalities (in the case of the 2012 protest) whose voices the government could not ignore. In 2012, after extensive deliberations and consultations with significant sections of 
the populace, the labour unions and their allies demanded an immediate reversal of the fuel price rise. In order to gain 'holding power', the labour unions changed tactic from talk to marches convincing Nigerians to embark on indefinite general strikes, mass rallies and street protests across the country.

In 2007, the unions questioned why the government was hiking prices despite over N350bn being appropriated in the 2007 budget for a pump price subsidy on petrol and kerosene (Social Action 2012). In 2012, Professor Tam David West, a retired professor of virology at the University of Ibadan and former Petroleum Minister, and Dr Izilien Agbon, a Nigerian energy expert based in the US, both insisted, rather hyperbolically, that the subsidy itself did not exist (Social Action 2012), thus opening up speculation as to whether the government diverted money allocated for the subsidy into other activities.

Civil society organisations in particular have been vehement in their opposition to subsidy removal. They have argued that what the government has been subsidising is corruption and not oil as people have been made to believe (BBC 2012; Ering and Akpan 2012). They have emphasised the cruel paradox of a leading oil producing country that has to resort to extensive importation of refined petroleum products. They have urged the government to fix the four existing oil refineries and to build more in order to halt the nightmare of importing refined petroleum products 'through their crooked friends whom they camouflaged as "cabal" (Social Action 2012).

Generally, in the cases of 2007 and 2012, the organised wave of the protests drew on existing resources such as NLC's nationwide organisational presence, and existing leadership resources in the church and labour organisations, which contributed significantly to the success of the protests. The role of these actors and their organising capacity is much more pronounced in the 2012 protests. For example, Tunde Bakare, the popular pastor of a large congregation in Lagos, led Occupy Nigeria. The NLC, the Trade Union Congress (TUC), the Save Nigerian Group, Campaign for Democracy, the Nigerian Medical Association, academics, and students as well as artisans organised the protests in Ekiti State in 2012. These were led by the Catholic Bishop of Ekiti, Bishop Felix Femi Ajakaiye. These actors brought their leadership skills and experience to bear. Material resources were present too. Protesters were given sachet water and other drinks for free. Symbolic resources were aplenty: for instance, Christians and nonChristians provided security for Muslim protesters when the latter had to pray. Popular Nigerian artists performed for the crowd of protesters.

Struggles over fuel prices in Nigeria have promoted some level of accountability and have led to some reforms in the petroleum sector. An example is the Subsidy Reinvestment Programme (SURE-P) initiated by President Goodluck Jonathan in 2012. The programme was introduced to fast-track development in answer to fuel subsidy-related protests. It was designed to complement the other 
development programmes at the three levels of government, and included an investment of funds obtained from the subsidy programme in specific sectors of the economy such as maternal health. Other examples including the Ad-Hoc Committee (to verify and determine the actual subsidy requirement) and the Presidential Committee (to verify subsidy claims on the heels of protests and allegations of subsidy scams), have not been sustained (KII 09). While SURE-P recorded progress in aspects of social protection and welfare, some of the other interventions tightened the process of subsidy reimbursement and reduced corruption somewhat.

Protests strengthen democracy in the sense that citizens freely vent their anger when the government appears to be insensitive to their needs. Some of our interviewees saw fuel protests as a referendum on the government, a message that says government cannot always have its way. One of them said: 'What we are doing partly is putting roadblocks on the road so that government will not be able to ride roughshod over the people. They have bumps and roadblocks to contend with' (KII 05).

However, it is important to note that citizens do not just protest. They have to be empowered to believe they can change the situation. From the interviews and the FGDs, the role played by organisers and motivators, especially organised labour and opposition politicians, in the protests was emphasised.

Frequent fuel-related protests in Nigeria have created a culture in which citizens have been empowered to challenge constituted authority in order to make the government more responsive to the plight of the public. This empowerment, however, does not seem to have strengthened accountability on the fuel importation and the subsidy issues. Neither has it translated to other governance issues like a more serious handling of corruption. A respondent observed:

Protest can just once in a while flash point beyond late episodic protest and beyond those episode [sic], it really does very extremely [sic] little to put in place a proper transparency and accountability frame work, because those actually protesting have limited leverage over the government... when government does not need anything from you, it's difficult to be in a position to demand accountability from that government. (KII 10)

Similarly, another respondent argued:

I don't think this translates to wider accountability. For example, Nigeria's greatest problem is high public corruption. It is why Nigerians don't enjoy good schools, health, etc. But I have never seen Nigerians protest over corruption and challenge it the way they 
have done over fuel. Holding government accountable in [the] energy sector has not spread to other sectors. (KII 06)

Faced with an escalation of mass protests, governments are likely to make temporary concessions to dampen them, while also using police or armed forces to repress protesters, and, then, to reintroduce the same reforms that were rejected by the people at a later date. An episode of energy protests may, thus, be followed by new restrictions aimed at preventing mass protests, affecting the extent to which protesters are able to hold government to account over future rounds of reforms.

Our respondents, who monitored and participated in the 2012 protests, felt that government actions were 'effective in terms of cosmetic reforms' (KII 09). The protests were not viewed as a threat to peace and security, but became seen as a threat to government survival, after they were hijacked by opposition politicians. Government policy position with regards to protest did not change either before or after the 2012 protests. Given that accountability is still very low, policies since the protests have only cosmetically taken cognisance of social protection (KII 09).

This prompted some of the respondents to suggest that what happens during and after protests is a function of 'power; it is about balance of forces' (KII 05). If the government feels threatened, it can react by sending out troops, which was exactly what President Jonathan did in order to stop the January 2012 protest. He deployed troops with the instruction to take over the streets of Lagos in 24 hours. When threatened, government use military force to repress protests. Once the streets are cleared, government carries on like there would never be another protest. Another government response to the 2012 protests, a different potential avenue for accountability, was the legal process that ensued from 2012 onwards, which the paper now turns to, followed by a discussion of other participatory policy spaces that may have opened up as the result of protest.

\subsection{Legal accountability and reforms}

The price hikes that led to the 2012 protest need to be seen in relationship to the complex management processes of fuel subsidy schemes. While the government claimed in December 2011 it could no longer afford subsidies, in fact billions of Naira had leaked through this complex of allegedly fraudulent actors, involving the NNPC, PPPRA, Department of Petroleum Resources (DPR), port authorities, multiple private actors, banks, and politicians (Kayode-Adedeji 2012).

The nexus of actors involved in Nigeria's importation and subsidy schemes has varied over time, with successive governments having played a prominent role themselves. Also, schemes for allocating licenses to exploit oil fields are the subject of controversy and corruption allegations involving international private 
actors (Oseni 2017; Hildyard 2018). Opposition actors have labelled the actors involved in the importation and subsidy schemes as a 'cabal' that have benefitted from subsidies (Ogidan 2020). International private actors have also been implicated in such allegations. Research respondents suggested that complex connections exist among multiple international private actors or 'marketers' using the loopholes in tender processes and subsidy schemes. According to one respondent, an independent oil and gas consultant (KII 12), there was and continues to be a lot of 'hidden politics' behind the acquisition of Petroleum Motor Spirit (PMS), and the subsidies paid to importers. In the past, this had to do with the high number and complex networks of suppliers. By 2011, this culminated in an alleged subsidy scam involving shady accounting of payments to PMS-selling firms. When the government had accrued a four-year backlog in payments, it decided to work with 'slots' to regulate the number of suppliers and volume of PMS (KII 12). Eventually, under the Jonathan administration, 121 companies were added to the subsidy management list, totalling 140 importers (Oseni 2017).

The state-owned oil company NNPC is accountable to no one. (...) The number of fuel importers rose from 5 in 2006 to 10 in 2007, 19 in 2008 and 140 in 2011. This decision taken by PPPRA was one of the biggest causes of fraud. Many firms only existed on paper and collected subsidies on fuel that never existed.

(Reuters 2015)

Following the widespread protests of 2012, the legislature decided to investigate allegations of sleaze in the oil subsidy programme by setting up the Ad-Hoc Committee to Verify and Determine the Actual Subsidy Requirement under the chairmanship of Honourable Farouk Lawan. After hearings from all stakeholders, spanning three months, the committee reported:

We found that the subsidy regime as operated between the period under review (2009-2011) was fraught with endemic corruption and entrenched inefficiency. Much of the amount claimed to have been paid as subsidy was actually not consumed PMS (petrol). Government officials made nonsense of the PSF [Petroleum Subsidy Fund] guidelines due mainly to sleaze and, in some other cases, incompetence.

(House of Representatives 2012)

While President Goodluck Jonathan faced pressure to dismiss some senior officials, it was believed many were his close allies, and it was alleged, though not proven, that he also benefited (BBC 2012). Six oil companies and twelve individuals faced charges in 2012, including staff of the PPPRA (Abdulah 2012). The Economic and Financial Crimes Commission (EFCC) withdrew charges 
against four suspects (Premium Times 2012). Yet, by 2014, 17 oil marketers and 23 companies were on the EFCC's list to face trial (Oseni 2017). Among the suspects were key political actors and leaders of private oil firms that operate internationally (Mohammed 2012).

The finance minister set up a technical committee, which later became a presidential committee, to verify subsidy claims. The presidential committee found evidence of fraud and abuse of the subsidy system. In one instance it found that 'there were subsidy claims for which there were no shipping documents or evidence of payments for the products in foreign exchange. Various other overpayments, wrongful claims, and breaches of the Petroleum Subsidy Fund guidelines also were detected' (House of Representatives 2012: 39).

The landscape for importers of PMS changed in 2017 (under President Buhari) when private oil marketers who bought PMS from NNPC stopped importing the commodity due to an increase in crude price as well as foreign exchange fluctuations (Olisah 2020). The import of PMS then rested solely with NNPC as it took over from the private actors. According to our interviewees, this contributed again to opaqueness about subsidies as it concentrated the power of exporting the crude, and importing the refined, within the hands of the NNPC. Thus, it sold crude oil, and spent the proceeds to buy refined fuel, and remitted whatever was left to the government as its revenue from oil.

Some of our respondents believe the government had a vested interest in controlling the import, because funds do not go directly into the federal accounts but remain with the NNPC, and the presidency and other actors have more direct access to these funds. The media drew attention to the opacity of 'underrecovery' in both the NNPC's and national budgets under Buhari, while the NNPC is under limited oversight (AFP 2018).

The final observation with regard to fuel protests is that following such episodes, policy reform proposals should include significant efforts for inclusive and participatory policy spaces. These efforts could include consultation with affected groups, attention to the impacts of subsidy reforms, specifically on poverty and inequality, and policies for addressing adverse effects. Evidence of such spaces and participatory efforts, and of their institutionalisation within government processes will be evidence that voice and teeth have together strengthened mechanisms of accountability to affected groups.

Our study suggests that often the voices of various citizens' representatives are built into social policies that emerge on the heels of protests. For instance, many CSOs gain visibility and popularity when their voices and action get media attention. Many CSOs have been strengthened during this process with increased executive and legislative interaction. Some of our respondents argued 
that there is a 'broad movement in the country in terms of demanding for accountability that is not necessarily linked to fuel subsidy' (KII 06). People are demanding accountability from those in authority. Some respondents felt that it is this pressure from citizens for example, that led government to start publishing revenue allocations to states and local government councils, and to join the Open Governance Initiative, which compels governments to publish all financial transactions for citizens to see.

However, the challenge is whether the pressure can be sustained long enough to keep those in authority committed to agreed governance changes, or even whether such pressure can ensure the piecemeal changes/gains are sustained and not subverted by future regimes. For example, in an effort to conserve the environment, the Nigerian government at one point agreed to subsidise kerosene in order to expand access, and dissuade people from using wood for cooking. This became a policy in the 1980s that benefited the poor. Two decades later, the subsidy on kerosene was completely removed. Citizens then switched to alternative sources, including the use of wood. It is difficult to identify instances where struggles have empowered ordinary citizens and groups to take more control over policies that influence their energy supply generally; not least because protests hardly open the opportunity for meaningful participation in policy processes. As one respondent observed:

There is always very limited opportunity for them [citizens] to participate in the policy reforms. Those who even have the little opportunity to participate in the process are more of the organised civil society, which is [sic] the NGOs and unions but citizens have limited opportunity to engage the government. As at today [sic], government does not really have any functional feedback mechanism for collecting feedback, for engaging the citizen on critical issues like this... the only people who can truly engage are the unions, NGOs, organised private sectors and maybe few politicians. (KII 10)

Moreover, these struggles do not afford citizens access to policymakers. Instead, they focus policymakers' attention on organised civil society groups and labour unions. These groups are the ones who get to sit with government officials to negotiate terms of peace and settlement. A participant in a FGD discussion noted:

I believe that NLC know how to stir people up and make them want to protest. They do this to get the government's attention. However, when they get to the negotiating table, they do not put the masses into consideration. They usually work for their own interests and so 
many people have become disillusioned and no longer show interest in protests. (FGD 04)

Ordinary Nigerians in the streets who are at risk of injury or death from protesting do not have the opportunity to engage with government. It is the visible leaders of civil society groups and labour unions who become the voices of citizens. KII respondents noted that most of the leaders who have emerged from the struggles have become major voices in relation to government fuel-related policies, and their opinions and views are regularly courted. This suggests that there exists a feedback mechanism between citizens and their government, but it has been 'hijacked' by the leaders of labour movements, NGOs, and CSOs who pretend to be the 'voices' of the people while actually serving their own interests. To this extent, the fuel protests give them some level of influence with the policymakers. According to one respondent:

Largely speaking, they [protests] don't lead to actual response from government. From our engagement with both NNPC and the presidency, there is an understanding/agreement that this subsidy needs to be taken away. The resistance we have to the removal right now is from his political party (President Buhari's ruling All Progressives Congress), because removing subsidy at the moment will lead to a situation that will make the All Progressives Congress (APC) unattractive for election so that is the dilemma right now. Majority of all their policies are not tied to protest but to priorities of those who funded them to power of reality, those who have leverage over them. (KII 10)

In conclusion, when episodes such as the 2012 fuel protests are joined and/or led by labour unions, they have the significant effect of grounding social and economic activities and effectively shutting down the country. As a result, they attract both national and international attention, more so as Nigerians in the diaspora embark on solidarity protests in Europe and America. When the 2012 protest intensified, elite division emerged when the legislature called on the executive to rescind its decision. Another common strand in the Nigeria protests is how the government reacts. A pattern is common for cases where the protests exploded into major episodes: the government makes concession following the escalation of the protests, and deploys the military to quell the protests when it feels threatened. However, the government does not engage in evolving legal restrictions on citizens' right to protest as a strategy for undermining attempts to protest in the future. The government appears to introduce some reforms to appease citizens, but the reforms, being cosmetic, are hardly inclusive. The government grants the token inclusion of a few protest leaders; but there is little consultation with affected groups, and rarely any institutionalisation. 
Finally, the court cases set in motion after the 2012 protest produced very limited accountability as, by 2017 , only four individuals were sentenced to jail for corruption in fuel subsidy schemes and made to refund the state (EFCC 2017). Compared to the total number of firms and individuals indicted, few have been sentenced. These prominent court cases have not resulted in more accountability in the management of fuel subsidies either. According to Publish What You Pay (PWYP) - a coalition working to build the capacity of civil society actors in understanding the Extractives Industries Transparency Initiative (EITI) process and disseminating findings from EITI's reports - there was no political incentive to secure justice under the President Jonathan administration (Oseni 2017). When the NNPC was in the process of restructuring under President Buhari, two private actors received NNPC licenses and contracts while their previous cases were still in court (Page 2016). The management of fuel subsidy schemes thus remains opaque and outside of public oversight. 


\section{Popular protests and empowerment over policymaking on energy provisioning}

This section of the paper focuses on whether or not struggles over fuel pricing and subsidies caused a shift of power in favour of citizens when it came to energy provisioning policies in Nigeria. There are reasons to suggest that popular protests do produce some form of empowerment. In their study of the \#BBOG movement in Nigeria, for instance, Aina et al. (2019) showed that the release of some of the abductees would not have been possible without the pressure mounted by the movement on the Nigerian government. Not only this, the movement also empowered women in diverse ways such as training them to be activists who could seek to hold government accountable.

A cursory look at the trajectory of fuel protests and their consequences in Nigeria provokes an affirmative response in support of protests leading to empowerment over policymaking. For instance, some of the times that citizens protested against hikes in fuel prices, the protests led to either a downward review of the pump price of petrol or the introduction of social welfare palliatives or both (see Table 1.1). This shift can become an incentive for the next struggle: with activists and union leaders reminding weary protesters of the efficacy of past protests. The outcome of such successes on a continued basis might be greater claim making and a sense of empowerment on the part of citizens. These are both aspects of empowerment.

However, the data at our disposal makes such conclusions tenuous, if not outright untenable. First, as noted in the previous sections, the regularity of the protests themselves suggests evidence for their inability to effect long-term policy shifts that serve the poor. The trajectory is predictable: the government withdraws the subsidy and, therefore, the prices of fuel products go up; activists and labour unions mobilise crowds in Lagos and other cities, and also embark on strikes; protests erupt; the government invites labour union leaders (not activists, not the masses) for negotiation; part of the subsidy is restored and the prices of fuel products are reviewed downward but not to the original price. The protests then end until the government attempts to tamper with the subsidy again. If the protests empowered people to influence government policies, that would have been at a level that is fundamental enough to preclude the need for future protests.

Our event catalogue analysis suggests that in-between major protests such as the ones in 2007, 2009, 2010 and 2012, there were pockets of small protests relating to fuel supply and consumption. For instance, in July 2008, Nigeria's fuel 
tanker drivers began a strike action to protest at high fuel prices and the poor state of the country's roads, which they said was a huge hindrance to business. This suggests that the issue of fuel pricing hardly ever leaves the public limelight. These smaller-scale protests have also not led to policy decisions that solve the problem in favour of the poor in the long term.

Second, the concessions or victory granted to the people as a result of the protests have ended up becoming a victory for the government. Both citizens and government officials have noted that very often, the government knew the protests would occur, it knew there would be negotiations, and that it would be forced to come down somewhat on the prices. So, it created a buffer in fixing the initial prices. A government official involved in the reform issues said:

The government would be determined to increase fuel prices and would say okay, they want to increase it to N10 from N8 but they know that people would scream and shout so they'd increase it to N12 so that everybody can scream and shout, and then they bring it to N10, which was their original intention. (KII 16)

It becomes a double gain for the government: it gets the price to where it originally wanted it, whilst also presenting the image of a compassionate government that listens to, and cares for its people. It also protects the image of the labour leaders as people who accomplish change. As an interviewee put it: 'So labour would not lose face before their people and government would have achieved what they want to achieve' (KII 13).

Third, the role of organised labour in the protests invites further interrogation of the extent to which protests empower the people to influence policymaking in the energy sector. In all the three major and five minor protests under focus, organised labour played a leading role under the umbrella of the NLC, or the Trade Union Congress of Nigeria (TUC). Joined by activist groups, they mobilised their members and other citizens to take to the streets. However, when it was time to negotiate, government negotiated with organised labour. In many cases, in addition to reducing the pump prices of fuel, government introduced palliatives for civil servants. Such palliatives included wage increases. The implication is that the ordinary citizens outside organised labour had less to gain from the struggles.

While it is true that protests produced little beyond the façade of partial price reduction, it is important to note a proactive policy response from the President Jonathan administration in 2012 following the reduction of the subsidy: the creation of the Subsidy Reinvestment Project (SURE-P, described in Section 4). Even though the government was forced to retain some subsidy, the SURE-P project took off and worked whilst that administration lasted; however, it did not survive in its original form for much long after. 
While our research evidence shows that the protests on the whole produced only a few short-term shifts, it is important to note that there were occasions that protests produced nothing at all. Knowing why some protests yield even just a little success, while others do nothing can shed light on the potency of protests in influencing government policy. Unlike the violent protests of 2012 which led to the creation of SURE-P, the 2016 protests did not result in a change of government policy. In 2016, the Muhammadu Buhari administration withdrew the subsidy and the pump price jumped from N87 to N145 per litre. The NLC followed its usual path. It called a strike and urged people in the informal sector to join in resisting what the NLC called the 'criminal' 67 per cent rise in petrol prices (BBC 2016). For its part, the government argued that the subsidy 'costs the government $\$ 2.7 \mathrm{~m}$ a day and there is no provision for it in the recently approved budget' (ibid.). The National Union of Road Transport Workers, Trade Union Congress and some activists organised marches and disrupted traffic in Lagos. All these lasted only a few days as most Nigerians did not join the strike or protests. The price of fuel stayed at N145 per litre.

Our inquiry among the citizen members of our FGDs about the reason for the difference in their reactions to these two events threw up a number of factors. First was the goodwill that the new government of President Buhari enjoyed with most people at the time. Whereas there had been a general discontent with the government in 2012 as cases of immense corruption in the oil sector were being reported regularly, in 2016 there was a higher level of trust in the government, being a new administration led by someone who had been known for integrity and transparency. A discussant said:

Knowing who Buhari was in $1985 \ldots$ people were like this man that did this, did that in 1985 is coming with something different and that we would have something better [sic]. So there was goodwill... they were like don't worry, subsidy will be removed and all [sic]... so people were ready to work with him (Buhari). They were like we support you [sic], remove the subsidy, things would be better. (Female, FGD 07 middle-income)

Buhari's reputation as a strict disciplinarian and transparent person with zero tolerance for corruption could have helped Nigerians to trust him and accept the removal of the subsidy with little or no resistance.

The second factor was a growing understanding, especially among the middleincome class, of the nature of the subsidy regime in Nigeria. By 2016, people had understood that there was corruption in the subsidy system and that fighting for the retention of the subsidy was actually fighting for the interests of the 'subsidy cabal'. A discussant put it aptly: 'Ko si subsidy kankan; sosapo lo wa' [Meaning; 'there was/is no subsidy; there was/is only pocketing of the nation's money'] (Male, FGD 04; low-income). 
Another said: 'People have already been complaining about this subsidy. They felt let this subsidy disappear. Let us see the reality' (Male FGD 07, middleincome).

Therefore, one unexpected achievement of the Jonathan administration was the exposure of the rot in the subsidy regime and the creation of an awareness of that among the people. This later worked in the favour of the Buhari administration which followed Jonathan. The Buhari government was also involved in a much publicised fight against corruption and the corrupt leaders of the previous government.

The third factor was the role of 'invisible big actors' in 2012 which was missing in 2016. Discussants mentioned how some elites enabled the 2012 protests by providing vehicles to ferry people from different locations to the centres of the protests; some also provided food and drink to people at the centre, making it possible for protesters to carry on for days; others funded protest entertainment from famous stars, which again kept protesters glued to the protest centres. These invisible big actors did not perform this role in 2016. Members of the opposition Action Congress of Nigeria were also mentioned as actively motivating and supporting the protests at the grassroots level in 2012. A discussant said:

They gave people money to go and protest. They brought money. They made buses available. They cooked food and took it to the place of protests, to protest against Jonathan. They were capitalising on people's poverty, but they were working for what they would eat. Now they get to power and they're doing what they like. None of them are fighting for our interest. (Male, FGD 06, middle-income)

The efficacy of these invisible actors in their support for the 2012 protests was not doubted by our discussants. These actors were in opposition in 2012 when the protests erupted, but in government in 2016 when the fuel price rise was met with little resistance. The actors also had the support of the media, and of civil society activists in the 2012 protests.

Protest fatigue is another important factor in the 2016 episode. Rather than developing confidence in their own agency and ability to affect the government's energy policy, protesters appeared to have acquired some level of 'protest fatigue' by 2016, partially as a result of constantly having to revisit the same issues without achieving any apparent long-term gains. Some citizens were, therefore, no longer particularly motivated to join in protests. A common argument is that the so-called concessions sometimes made by the government in response to popular struggles were little more than a 'consolation prize', designed to pacify irate citizens, while also failing to fully address the issues that triggered the protests in the first place. A discussant stated: 
This occurred in Yaba, we joined Gani Fawehinmi for the protests. It was as a result of the tear gas that I got the wound that resulted in this scar. Many people died, and those that died have wasted their lives. Nowadays no one wants to protest. We are resigned to our fate. We do not want to die. After all, the government knows that if they increase it, people will protest and they will reduce it a bit and no one can hold the government accountable. (Male, FGD 02, lowincome)

Another discussant, who had also engaged in the 2012 protests, expressed similar reasons for opting out of further protests, saying; 'Why should I go again in 2016? The one of 2012, what came out of it? What was the result?' (Male, FGD 09, low-income).

In addition to protest fatigue, some expressed fear that the security agents were more high-handed under the current administration than they were under the previous one, thus making protests highly unattractive.

In assessing the potency of popular struggles to empower people in relation to policymaking in energy provisioning, lessons from Nigeria show that while protests usually follow increases in fuel pump prices, protesters' demands run the gamut of the various aspects of government energy policy. These demands in the case of Nigeria ranged from the reversal of petroleum pump prices, to other demands concerning management of petroleum resources and oil installations, especially Nigeria's refineries, and requests for an increase in the minimum wage.

However, beyond the occasional reduction of fuel prices, the other demands do not appear to have had much impact on government decisions. During the 2012 protests for example, protesters in Lagos made demands that the government should conduct a referendum before implementing the controversial fuel sector deregulation policy. A key aspect of that policy was the removal of the subsidy. However, while protests yielded a marginal reduction in the initial price hike, a referendum did not appear to even have been considered. The policy remained in place. On the other hand, protesters in Abuja during the same 2012 protests had a different set of demands: they expected the government to not only reinstate fuel subsidies, but to unveil an updated budget showing that the subsidy funds had been duly reallocated. Protesters in Benin City wanted the resignation of the finance minister and further demanded that fuel prices be reduced to N39 rather than the pre-increase N65. Needless to say, most of these demands were largely ignored. 


\section{Transnational actors and the contentious political economy of energy}

From the previous sections, it is clear that the activities of actors and institutions involved in the oil and fuel sector are complex and opaque. This complex landscape is characterised by informal networks between so called 'marketers' and political actors, including government officials and agencies. Transnational actors are part of the landscape. While the perspectives of some international financial institutions are visible to the public due to their press statements and reports, the role of other transnational actors and the extent of their influence remains relatively unclear.

This section reviews the role of several transnational actors in Nigeria's political economy of fuel subsidies. It remains unclear the extent to which the Government of Nigeria is receptive to pressures of transnational actors in its considerations about reforming fuel subsidies.

As indicated in previous sections, the World Bank and IMF, as well as some other donor agencies are in favour of scaling down fuel subsidies. For Nigeria specifically, the IMF claims the 'removal of the implicit subsidy would reduce income inequality and, if combined with targeted transfers, could result in a decrease in the poverty gap while leaving significant fiscal space for other productive expenditures' (IMF 2019b: 23). It frames fuel subsidies as funds depleted from important service sectors that benefit the population, and that, ultimately, subsidies cost human lives (Naira Metrics 2019a). One academic expert indicated that Nigeria has not received loans from the IMF since the structural adjustment programmes of the 1980s, hence, the IMF has not been able to enforce fuel subsidy reform by setting this as a condition for loans. ${ }^{6}$

The World Bank has a larger office in Nigeria than the IMF and a wide array of projects and loans. This includes the recent approval of a US\$3bn loan to improve the electricity sector (Awojulugbe 2019). A few weeks after this approval, Nigerians in the diaspora protested in Washington DC against the Nigerian government taking on more loans, saying the country would be 'economically colonised' and funds would be corrupted (Ohaegbu 2019). The World Bank itself has repeatedly recommended that Nigeria needs to reform fuel subsidy policies as they do more harm to the poor than good, along similar lines as the IMF (Ojoye 2019). While the World Bank has programmes and investments in Nigeria, it has not formally made reform conditional to receiving

6 Pers. comm. with academic expert, 27 April 2020 
loans, projects and investments. It is unclear how the IMF and the World Bank exercise pressure on the Nigerian government in other more subtle ways or in negotiations. The staff of the IMF and the World Bank were unavailable for interviews.

A representative of the NPEC acknowledged that the World Bank and the IMF raise subsidy removal in negotiations over loans, and that certain ambassadors do not miss any opportunity to state that the Nigerian government needs to cut subsidies (interview 13). Yet various research respondents felt that the pressure of international actors like the World Bank, IMF, and important donor governments and international banks is not effective (interviews 12, 13). In 2019, the Minister of Finance, Zainab Ahmed, stated that IMF advice was 'reasonable' as funds could be used for other sectors, but that the federal government would not adjust fuel subsidies as there is no alternative to 'cushion' Nigerians (Naira Metrics 2019b). Among our respondents, however, some felt that government actors, and especially politicians, were more concerned about winning elections, alongside benefiting from networks involved in subsidy schemes, than about reform: the main reason political actors ignore IMF advice (KIIs 12, 13).

The Nigerian government has public sentiment on its side when it resists the IMF recommendations. The structural adjustment programmes in Nigeria had a devastating impact on the country's public institutions leading to a legacy of suspicion. Due to strong antipathy towards the World Bank and the IMF, the public does not object when the government refutes advice or conditions from these institutions. Additionally, opposition politicians have blamed the IMF for being behind austerity measures and fuel subsidy cuts, spinning this as part of the protest discourse. In 2012, the labour movement asserted that the World Bank and the IMF had engineered the fuel price increase. Suspicion was fuelled by IMF Managing Director Christine Lagarde's visit to Nigeria in late December 2011. Suspicion was also raised when Dr Ngozi Okonjo Iweala, a Managing Director at the World Bank, was appointed Nigeria's Minister of Finance in 2011. As a spinoff of the 2012 protests, supporters of Occupy Nigeria staged protests at the IMF offices in Washington DC. Thus, the IMF does not just influence dynamics around reform by giving out advice: its negative legacy triggers political actors to resist or mobilise against reforms.

As part of the response to the Covid-19 pandemic, the IMF put together loan packages for numerous countries. It has offered debt relief to many vulnerable economies, but Nigeria was not one of these (Udo 2020). However, the IMF has provided US $\$ 3.4 \mathrm{bn}$ in 'emergency financial assistance' under its rapid financing instrument to support Nigeria's efforts in addressing the severe economic impact of the Covid-19 shock and the sharp fall in oil prices (IMF 2020). This followed a request from the Nigerian finance minister (Carsten 2020) who underscored that any IMF loans would be unconditional (AllAfrica 2020; Udo 2020). It emerged, 
however, that the federal government actually pledged not to reintroduce recently removed fuel subsidies. It remains to be seen whether this commitment will be kept by the Nigerian government once global fuel prices stabilise. 


\section{Conclusions}

The overall aim of this study is to understand how, and under which conditions, struggles over energy access in Nigeria produce accountability and empowerment.

Globally, access to energy has been the reason for many citizen protests. However, while some of these produce outcomes such as empowerment of citizens or holding government accountable, many do not. While some last over a period of time and escalate into major conflicts leading to enduring policy decisions, others occur briefly succumbing to government repressive response or just fizzle out as protesters get tired, thus, leading to transient or even no policy decisions. As a result, it has been important to examine what makes struggles over energy access escalate, and what makes them lead or not lead to empowerment of citizens and accountability on the part of government.

Nigeria's dependence on crude oil exportation, as the main source of government revenue, makes the economy vulnerable to international price determinations and fluctuations. This means that shocks in the international oil markets are inevitably and acutely felt at the national level. In addition to this, there is an intricate and sensitive, even direct, link between essential domestic consumer commodities and the price of fuel products, such that when the fuel price goes up, the ripple effect is felt immediately on the price of essential domestic consumer commodities, especially transport fares, food items, and house rents. This economic vulnerability and its interconnectedness often attract widespread protests in the country.

The fuel subsidies introduced in the 1970s should have served as the buffer between international oil prices and the market pump prices of fuel products at the domestic level, and to protect citizens against external shocks. However, the Nigerian government's inability to deal decisively with corruption in the subsidy process (a marker of state ineptitude and leadership deficit) enabled subsidy costs to rise to levels that could no longer be sustained by the nation, leading to the government's continual attempts to remove or reduce the subsidy. In addition, the government's inability to repair and maintain its refineries, and to deal decisively with those who sabotage them (another marker of state ineptitude) has made it impossible for Nigeria to liberate itself from the shackles of fuel importation, and to meet its domestic needs. This continues to make subsidy necessary, and yet unbearable. The government's continual attempts to remove the subsidy invariably leads to fuel price increase, often followed by conflict and protests.

These protests range from mild and brief, to severe and disruptive, the latter leading to many days of economic shutdowns and loss of lives, leading to the 
question: what makes energy protests in Nigeria escalate into serious episodes of violence? Answering this question requires paying attention to the two types of protests: the short and mild such as the 2016 protest which hardly took off before it died down, and the violent and drawn-out such as the 2007 and 2012 protests in which several people died.

\subsection{What leads to the escalation of protests?}

Our findings suggest that fuel protests escalate into episodes of violence when there is a network of experienced protesters, labour unionists, religious leaders, and popular opposition politicians providing ready leadership, and organisational and symbolic resources, which energise the movement. These leaders may have a keen understanding of the crowd, of how to draw them out, and how to sustain their energy. In 2012, these leaders invited popular entertainers that kept protesters going for days at protest squares; they also provided material incentives - food and water, especially - as well as buses to convey protesters from and back to different parts of the city.

Second, the protests easily become explosive where there is widespread discontent with the government. In 2012, there were too many incredibly damning allegations of corruption against the government and its agencies. The almost daily exposures of fresh corruption cases had turned citizens against the government and provided fodder for opposition and labour unions' speeches and mobilisation. This partly explained the mildness of the 2016 protests as citizens hung a lot of faith and hope in President Buhari's reputation as a strict disciplinarian and transparent person with zero tolerance for corruption. Even when the Buhari government removed the subsidy and the prices of fuel products went up high, it was believed to be in the interest of the nation.

Third, protests escalate when there is no opportunity to discuss fuel pricing policy by citizens. Even when such an opportunity existed, the discussions were often rushed. In fact, in most cases, avenues for discussing fuel pricing are open only after the government has tampered with the prices and tensions have risen.

Fourth, protests may escalate where there is no protest fatigue. Part of the reason that the 2016 protest died quickly was due to protest fatigue among citizens. Fatigue sets in when citizens fail to see any tangible results of their protest efforts, especially in terms of policy reforms that attend to their demands. Protest fatigue therefore affects the capacity of the next protest to push the boundary of empowerment and accountability.

Finally, repressive responses from government, such as those witnessed in 2012 , only manage to hasten the escalation of protests into violent episodes. The more heavy-handed security men become, the more violent and disruptive the protest seems to be. On the other hand, the harsh response from 
government in 2012 also informed citizens' decisions not to participate in subsequent protests.

\subsection{Do protests result in, or support, accountability and/or empowerment?}

Another concern of this study is to examine whether or not fuel protests promoted accountability in Nigeria. It seemed struggles over fuel prices in Nigeria have promoted some level of accountability, especially in cases such as 2012 where protests led to policy decisions and actions by the government. Such decisions and actions, however, easily collapse because of lack of consistent demand by citizens, and sometimes because of a change in the political regime.

Frequent fuel-related protests in Nigeria have created a culture in which citizens have been empowered to challenge constituted authority in order to make the government more responsive to their plight. Whilst the government now knows it is challenged, it has still not strengthened accountability nor dealt with the importation and subsidy issues. Neither has the challenging translated to dealing with other governance issues like corruption.

Faced with an escalation of mass protests, Nigerian governments have made temporary concessions to dampen the protests, while also using police or armed forces to repress protestors, and then subsequently reintroducing the subsidy reforms at a later date. Such repressive responses to protests portray the government as unwilling to brook protests. This has the tendency to further narrow the extent to which protests would be deployed for accountability purposes.

Closely tied up with the accountability question is the extent to which energy protests empowered citizens over energy provisioning policymaking. For more than half of the times that citizens protested over a reduction of the subsidy, the protest led to either a downward review of the pump price of petrol or the introduction of social welfare palliatives or both. However, it is difficult to conclude based on this that the protests empowered citizens. This is because energy policy making in Nigeria is complex, carried out amongst an array of vested interests lodged in both national and international entities, determined by knowledge and expertise not easily available to the ordinary citizen, and often conducted with little or no transparency. Empowerment in such a process would need to be evidenced by public and open consultations, access to data and information, and representation of ordinary citizens in the governance and determination of such policies. In spite of the role of the Nigerian federal legislative houses, this is not often or effectively the case. However, in 2012, the federal legislative organs did respond to, and institute processes to attack some of the irregularities in the management and governance of the Nigeria fuel 
subsidy regime. The 2012 protests did lead to some official response, but we are unable to conclusively declare that it empowered citizens to demand and continuously extract legislative oversight of the oil sector from their elected representatives.

First, the regularity of the protests themselves suggests their inability to effect a long-term policy shift that serves the poor. Second, the concessions or victory granted to the people as a result of the protests ended up becoming appropriated as a victory for the government. As a response to the protests, government often managed to 'reduce' the price to where it originally had intended it to be, yet make it look like the protesters had won. Third, the bulk of the benefit often went to organised labour, who amplified their voices in negotiating with government, in some cases obtaining personal or unionised gains in the process. This is despite the fact that the protests were embarked upon by people from all sectors, including the unemployed.

In assessing the potency of popular struggles to empower people on policymaking in energy provisioning, lessons from Nigeria show that while protests usually follow increases in fuel pump prices, protesters' demands run the gamut of the various aspects of government energy policy. These demands in the case of Nigeria ranged from the reduction of petrol pump prices, to other demands concerning management of petroleum resources and oil installations, especially Nigeria's refineries. Recurrently, they included requests for an increase in the minimum wage. However, beyond the occasional reduction of fuel prices, the other demands do not appear to have had much impact on government decisions or citizens' capacity to consciously demand that their representatives in parliament provide the required oversight for the oil sector.

As a result, on the whole, citizens do not seem to feel empowered. They are largely uninformed about existing policies, unsure about policy change processes and convinced that the government is inaccessible so there is no point embarking on protest or policy change efforts.

\subsection{What role do international actors play in these crises?}

The final concern of this study is the role of transnational actors in the energy access crises. The World Bank and IMF, as well donor agencies, are seen to be in favour of scaling down fuel subsidies. For Nigeria specifically, the IMF claims the 'removal of the implicit subsidy would reduce income inequality and, if combined with targeted transfers, could result in a decrease in the poverty gap while leaving significant fiscal space for other productive expenditures' (IMF 2019b: 23). Along similar lines as the IMF, the World Bank too has repeatedly recommended that Nigeria needs to reform fuel subsidy policies as they do more 
harm to the poor than good. It however remains unclear the extent to which the Government of Nigeria is receptive to pressures of transnational actors in its considerations about reforming fuel subsidies, casting doubts on the efficacy of the externally driven recommendations.

What is clear, however, is the active collaboration of transnational actors in maintaining the opacity around the fuel subsidy process. First of all, oil firms have international networks and use loopholes in registrations and licensing to enable their actions to benefit from the schemes. Secondly, individual actors involved in subsidy corruption have been enabled by transnational financial networks that enable illicit flows of money.

It is also clear that transnational actors have supported the Government of Nigeria in fighting the subsidy scam. For instance, courts outside Nigeria have helped in bringing some of the beneficiaries of the scam to book. An example is the CEO of Capital Oil (Ifeanyi Ubah) who was charged by a court in the UK and had assets frozen worldwide - a process which required international actors' help.

\subsection{Lessons on action for empowerment and accountability}

We return to the question: did energy struggles empower people to hold public authorities accountable over energy demands in Nigeria? Our response to this question can be framed in the form of key lessons.

Lesson 1: Struggles over access to energy often yields some response from government (accountability) but those who benefit maximally from this response are usually not the marginalised and less powerful people who form the bulk of the protesters. Struggles over energy access in Nigeria, especially protracted ones, often end up in government negotiating with the labour unions.

Interestingly, the majority of those on the streets protesting are not members of organised labour, and they do not have an organised platform on which they can negotiate with the government. In a sense, therefore, protests over energy access empower labour unions, not the people, to negotiate with the government over energy access. While the result of the negotiations is often a downward review of energy prices which benefits both labour and other citizens, labour often succeeds in extracting extra benefits for its members that do not extend to those in the informal sector or private sector, or the unemployed. Among these non-beneficiaries are the poorest of the poor. This largely corresponds with the doubts expressed about unruly struggles by Hossain et al. (2018:37) that 'energy protests can sometimes pack a powerful political punch, it is not clear to what extent marginalised and less powerful groups benefit from the gains achieved, either materially or in terms of enduring forms of political power'. 
Lesson 2: Genuine energy protests can become a platform for opposition politicians who capitalise on the government's failure to achieve their political goals, and attain political power for their parties and themselves. These politicians portray their involvement and investment in the protests as being in the interests of the poor and of the nation, rather than a self-serving political investment. The protesting crowd is a multitude with varying and sharply different motives. Therefore, in trying to understand if popular struggles work, it is important to ask: work for whom and for what?

Lesson 3: While energy access protests often led to a downward review of fuel prices, they hardly ever lead to any long-term organisational, structural and/or governance changes. In other words, the 'victories' recorded by the protesters (such as price reduction and even wage increases) are short term and ephemeral and have soon been caught up by inflation. In some exceptional circumstances where (envisaged) protests led to the establishment of an elaborate social support agency, the agency worked fully for only as long as the regime that established it was in government. Scholars of empowerment and accountability are often wary of accountability that ends up being tokenistic rather than a genuine response to citizens' requests (Hossain et al. 2018). This lack of sustainable and enduring change is a manifestation of the nature of the state, politics and its institution, a condition that makes it possible for a new government to overrule, abandon and starve existing programmes and agencies.

Lesson 4: Protests originally targeted at improved energy access hardly remain so for long (Hossain et al. 2018). Often, they spiral into wider demands for good governance, for an end to corruption, and for a severance of the relationship with transnational actors, especially the IMF and the World Bank. In fact, the demands of protesters in Nigeria once involved the removal of cabinet ministers, and the president's resignation (See also Aina et al. 2019).

Lesson 5: The activities of transnational actors can be, on the surface, difficult to place and describe. Yet there are strong indications that they play a role in pushing for subsidy reduction. Therefore, attempts to understand the role of transnational actors must probe beyond their official claims and actions.

Lesson 6: For energy struggles to empower people to hold public authorities to account, however ephemerally, there is a need for some organising and significant resources. Notably, the skills and resources for these are hardly ever found among the less powerful and marginalised. This not only casts doubt on the widespread popularity of the protests, but also raises the likelihood that whatever concessions or benefits emerge as a result of the protests must first cater to the interests of the organisers and funders.

The outcomes of the struggles over energy access in fragile and conflict-affected contexts are severely limited by the very conditions that define the settings as 
fragile: weak institutions, elite capture, widespread corruption, and a citizenry that is protest-fatigued and disempowered. Frameworks that open up the civic space for dialogues between government and the citizens might produce better outcomes than protests do. Such spaces must widen and deepen the norms, institutions, values and practices of democracy in such a way that citizens, and their collective groups and associations are willing and able to effectively engage governmental actors and their agencies in encounters and dialogues that enhance opportunities to map out, implement and promote lasting policy options in the energy sector. 


\section{Annexe 1}

\section{Table A1 Chronicle of fuel-related protects in Nigeria}

\begin{tabular}{|c|c|c|c|c|c|c|}
\hline Year & Actors & Action & Duration & Spread & $\begin{array}{l}\text { Injuries } \\
\text { \& Deaths }\end{array}$ & $\begin{array}{l}\text { Policy } \\
\text { outcome }\end{array}$ \\
\hline 2007 & $\begin{array}{l}{ }^{*} \text { Labour/ } \\
\text { CSO/ } \\
\text { Activists } \\
{ }^{*} \text { Informal } \\
\text { sector } \\
\text { businesses } \\
{ }^{*} \text { Citizens }\end{array}$ & $\begin{array}{l}{ }^{*} \text { Talk/ } \\
\text { negotiate } \\
{ }^{*} \text { Rally/ } \\
\text { marches }\end{array}$ & $\begin{array}{l}\text { Over two } \\
\text { weeks }\end{array}$ & $\begin{array}{l}\text { Lagos } \\
\text { (South } \\
\text { West) } \\
\text { and } \\
\text { Abuja }\end{array}$ & $\begin{array}{l}\text { Many } \\
\text { injured } \\
2 \text { died }\end{array}$ & $\begin{array}{l}\text { Partial } \\
\text { downward } \\
\text { review }\end{array}$ \\
\hline 2008 & $\begin{array}{l}\text { * Labour/ } \\
\text { CSO/ } \\
\text { Activists }\end{array}$ & $\begin{array}{l}\text { Talk/ } \\
\text { negotiate }\end{array}$ & $\begin{array}{l}\text { Less than } \\
\text { one week }\end{array}$ & $\begin{array}{l}\text { Lagos } \\
\text { (South } \\
\text { West) } \\
\text { and } \\
\text { Abuja }\end{array}$ & None & None \\
\hline 2009 & $\begin{array}{l}\text { *Labour/ } \\
\text { CSO/ } \\
\text { Activists }\end{array}$ & $\begin{array}{l}\text { Talk/ } \\
\text { negotiate }\end{array}$ & $\begin{array}{l}\text { Less than } \\
\text { one week }\end{array}$ & $\begin{array}{l}\text { Lagos } \\
\text { (South } \\
\text { West) }\end{array}$ & None & None \\
\hline 2011 & $\begin{array}{l}\text { *Labour/ } \\
\text { CSO/ } \\
\text { Activists } \\
\text { *Informal } \\
\text { businesses }\end{array}$ & $\begin{array}{l}{ }^{*} \text { Talk/ } \\
\text { negotiate } \\
{ }^{*} \text { Rally/ } \\
\text { marches }\end{array}$ & $\begin{array}{l}\text { About a } \\
\text { week }\end{array}$ & $\begin{array}{l}\text { Lagos } \\
\text { (South } \\
\text { West) }\end{array}$ & None & None \\
\hline 2012 & $\begin{array}{l}\text { *Labour/ } \\
\text { CSO/ } \\
\text { Activists } \\
\text { *Citizens } \\
\text { *Informal } \\
\text { businesses } \\
\text { *prominent } \\
\text { individuals/ } \\
\text { politicians } \\
\text { *External } \\
\text { actors }\end{array}$ & $\begin{array}{l}{ }^{*} \text { Talk/ } \\
\text { negotiate } \\
{ }^{*} \text { Rally/ } \\
\text { marches } \\
{ }^{*} \text { Barricad } \\
\text { e/ } \\
\text { disrupt }\end{array}$ & $\begin{array}{l}\text { More } \\
\text { than } 4 \\
\text { weeks }\end{array}$ & $\begin{array}{l}\text { All six } \\
\text { geo- } \\
\text { political } \\
\text { zone \& } \\
\text { Abuja }\end{array}$ & $\begin{array}{l}\text { Many } \\
\text { injured } \\
16 \text { died }\end{array}$ & $\begin{array}{l}\text { Partial } \\
\text { downward } \\
\text { review, } \\
\text { combined } \\
\text { with } \\
\text { Palliative } \\
\text { measures } \\
\text { (including } \\
\text { SURE-P) }\end{array}$ \\
\hline 2015 & $\begin{array}{l}{ }^{*} \text { Labour/ } \\
\text { CSO/ } \\
\text { Activists }\end{array}$ & $\begin{array}{l}\text { Talk/ } \\
\text { negotiate }\end{array}$ & $\begin{array}{l}\text { About a } \\
\text { week }\end{array}$ & $\begin{array}{l}\text { Lagos } \\
\text { (South } \\
\text { West) }\end{array}$ & None & None \\
\hline
\end{tabular}




\begin{tabular}{|l|l|l|l|l|l|l|}
\hline 2016 & $\begin{array}{l}{ }^{*} \text { Labour/ } \\
\text { CSO/ } \\
\text { Activists } \\
{ }^{*} \text { Citizens }\end{array}$ & $\begin{array}{l}{ }^{*} \text { Talk/ } \\
\text { negotiate } \\
{ }^{*} \text { Rally/ } \\
\text { marches }\end{array}$ & $\begin{array}{l}\text { Less than } \\
\text { one week }\end{array}$ & $\begin{array}{l}\text { Three } \\
\text { geo- } \\
\text { political } \\
\text { zones } \\
\text { and } \\
\text { Abuja }\end{array}$ & None & None \\
\hline $2017^{*}$ & $\begin{array}{l}{ }^{*} \text { Labour/ } \\
\text { CSO/ } \\
\text { Activists }\end{array}$ & $\begin{array}{l}\text { Talk/ } \\
\text { negotiate }\end{array}$ & $\begin{array}{l}\text { Less than } \\
\text { one week }\end{array}$ & $\begin{array}{l}\text { Benin } \\
\text { (South- } \\
\text { South) }\end{array}$ & None & None \\
\hline
\end{tabular}

*2017 protest was about fuel scarcity, not about price increase

Source: Authors' own

\section{Table A2 Not all fuel price increases attracted protests: 2007-20}

\begin{tabular}{|c|c|c|c|c|}
\hline Year & President & Increase & Increase \% & Protest \\
\hline 2007 & Olusegun Obasanjo & N65 to N75 & $15.4 \%$ increase & Yes \\
\hline 2012 & Goodluck Jonathan & N65 to N141 & $116.92 \%$ increase & Yes \\
\hline 2016 & Muhammadu Buhari & N87 to N145 & $66.67 \%$ increase & $\begin{array}{l}\text { Mild to } \\
\text { None }\end{array}$ \\
\hline 2020 & Muhammadu Buhari & N145 to N124 & $\begin{array}{l}\text { 14.5\% decrease } \\
\text { (market forces) }\end{array}$ & None \\
\hline 2020 & Muhammadu Buhari & N124 to N123 & $\begin{array}{l}0.81 \% \text { decrease } \\
\text { (market forces) }\end{array}$ & None \\
\hline 2020 & Muhammadu Buhari & $\begin{array}{l}\text { N123 to band } \\
\text { of } \\
\text { N140-N145 }\end{array}$ & Market forces & None \\
\hline 2020 & Muhammadu Buhari & $\begin{array}{l}\text { Band of } \\
\text { N140-N145 } \\
\text { to band of } \\
\text { N145-N148 }\end{array}$ & Market forces & None \\
\hline 2020 & Muhammadu Buhari & $\begin{array}{l}\text { Band of } \\
\text { N145-N148 to } \\
\text { price cap of } \\
\text { N151 }\end{array}$ & Market forces & None \\
\hline
\end{tabular}

Source: Authors' own 
Table A3 Timeline of events for three major protests: 2007, 2012 and 2016

\begin{tabular}{|l|l|l|l|l|l|l|}
\hline Year & $\begin{array}{l}\text { Fuel } \\
\text { price } \\
\text { increase }\end{array}$ & $\begin{array}{l}\text { Spontaneous } \\
\text { protests }\end{array}$ & $\begin{array}{l}\text { Mobil- } \\
\text { isation }\end{array}$ & $\begin{array}{l}\text { Organised } \\
\text { protests }\end{array}$ & Negotiation & $\begin{array}{l}\text { Policy } \\
\text { change }\end{array}$ \\
\hline 2007 & 29 May & 29 May & $\begin{array}{l}18 \\
\text { June }\end{array}$ & 21 June & 23 June & $\begin{array}{l}24 \\
\text { June }\end{array}$ \\
\hline 2012 & 01 Jan & 02 Jan & 4 Jan & 05 Jan & 13 June & 19 Jan \\
\hline 2016 & 14 May & - & 19 May & 20 May & - & - \\
\hline
\end{tabular}

Source: Authors' own 


\section{References}

Abdulah, A. (2012) 'Fuel Subsidy Scam: Bamanga Tukur's Son, 11 Others Charged', The Vanguard, 25 July, (accessed 27 April 2020)

Adebayo, D. (2020) 'A Socioeconomic History of Electrification in Southern Nigeria, 1898-1972', PhD thesis, Cambridge University

Adetola, O.S. (2015) 'Nigeria Democracy and Oil Subsidy Removal: Lessons and Consequences', Journal of Social Sciences and Humanities 1.4: 308-22

Aduke (2012) Hear the Voice against Subsidy Removal, music video (accessed 25 May 2021)

AFP (2018) 'Nigeria's Buhari Under Fire over 'Astronomic' Fuel Subsidy Bill', Agence France-Presse, 23 September (accessed 28 April 2020)

Aina, T.A.; Atela, M.; Ojebode, A.; Dayil, P. and Aremu, F. (2019) Beyond Tweets and Screams: Action for Empowerment and Accountability in Nigeria - The Case of the \#BBOG Movement, IDS Working Paper 529, Brighton: Institute of Development Studies (accessed 20 July 2021)

Akanle, O.; Adebayo, K.O. and Olorunlana, A. (2014) 'Fuel Subsidy in Nigeria: Contexts of Governance and Social Protest', International Journal of Sociology and Social Policy 34.1/2: 88-106

AllAfrica (2020) ‘Nigeria: Again, Nigeria Turns to IMF’, 12 April (accessed 21 April 2020)

Awojulugbe, O. (2019) 'Nigeria Planning to get First Tranche of \$3bn World Bank Loan in April', The Cable, 20 October (accessed 29 April 2020)

BBC (2016) 'Nigeria unions to resist 'criminal' fuel price hike', 12 May (accessed 13 August 2020)

BBC (2012) 'Nigeria Fuel Subsidy Report 'Reveals \$6bn Fraud', 24 April (accessed 23 April 2020)

BBC (2007) ‘Nigeria Unions Join Fuel Strike’, 18 June (accessed 1 July 2020)

Brown, C.A. (2003) We Were All Slaves: African Miners, Culture, and Resistance at the Enugu Government Colliery, Nigeria, Portsmouth NH: James Currey

Carsten, P. (2020) 'Nigeria seeks $\$ 6.9$ bln from Lenders to Fund Coronavirus Fight', Reuters, 6 April (accessed 27 April 2020)

DPR (2020) 'Nigeria’s Proven Gas Reserve now 203.16tcf, says DPR', Department of Petroleum Resources, 4 June (accessed 1 October 2020)

Eboh, C. (2007) 'Nigerian Strike Intensifies after Talks Fail’, Reuters, 22 June (accessed 10 August 2021)

Eesuola, O.S. (2015) 'Protest Demonstrations, Political Participation and the Law in the Era of Terrorism: Nigeria's Public Order Act and the United States' HR 347 in Perspectives', AFRREV IJAH: An International Journal of Arts and Humanities 4.2: 28-41

EFCC (2017) ‘N1.9bn Oil Subsidy Fraud: Court Convicts Wagbatsoma, Others', Economic and Financial Crimes Commission (accessed 28 April 2020)

Ering, S. and Akpan, F. (2012) 'The Politics of Fuel Subsidy, Populist Resistance and its Socioeconomic Implications for Nigeria', Global Journal of Human Science 12.7: 13-19

Flavour (2012) Nigeria Ebezina, music video (accessed 25 May 2021)

Galiana, I. and Sopinka, A. (2015) Benefits and Costs of the Energy Targets for the Post-2015 Development Agenda, Energy Assessment Paper, Copenhagen: Copenhagen Consensus Center (accessed 10 August 2021)

Gbadeyan, O.J. (n.d.) 'Social Protest and Protest Policing in Nigeria: An Analysis of the 2012 Fuel Subsidy Crisis Protest', unpublished

Hildyard, N. (2018) 'The World Bank, Red Flags and the Looting of Nigeria's Oil Revenues', Corner House Research (accessed 10 August 2021)

Hossain, N. et al. (2018) Energy Protests in Fragile Settings: The Unruly Politics of Provisions in Egypt, Myanmar, Mozambique, Nigeria, Pakistan, and Zimbabwe, 2007-2017, IDS Working Paper 513, Brighton: Institute of Development Studies (accessed 26 July 2021) 
Hossain, N. and Scott-Villiers, P. (2017) Food Riots, Food Rights and the Politics of Provisions, London: Routledge

House of Representatives (2012) Report of the Ad-Hoc Committee to Verify and Determine Actual Subsidy Requirements under Resolution No HR.1/2012, Abuja: Government of Nigeria (accessed 27 April 2020)

Ighodaro, C.A.U. (2010) 'Co-integration and Causality Relationship between Energy Consumption and Economic Growth: Further Empirical Evidence for Nigeria', Journal of Business Economics and Management, 11.1: 97-111

IMF (2020) 'IMF Executive Board Approves US\$ 3.4 Billion in Emergency Support to Nigeria to Address the COVID-19 Pandemic', Press Release No. 20/191, Washington DC: International Monetary Fund, 28 April (accessed 18 May 2020)

IMF (2019a) 'IMF Executive Board Concludes 2019 Article IV Consultation with Nigeria', Press Release No. 19/99, Washington DC: International Monetary Fund, 3 April (accessed 27 April 2020)

IMF (2019b) 'Staff Country Report - Nigeria Selected Issues', IMF Country Report 19/093, Washington DC: International Monetary Fund, 1 April (accessed 10 August 2021)

Jaja, S.O. (1982) 'The Enugu Colliery Massacre in Retrospect: An Episode in British Administration of Nigeria', Journal of the Historical Society of Nigeria 11.3/4: 86-106

Jonathan, G.E. (2018) My Transition Hours, Kingwood, TX: RevMedia Publishing

Kayode-Adedeji, D. (2012b) 'How Ifeanyi Uba of Capital Oil, Access Bank, Fraudulently Cornered Billions of Petrol Subsidy Funds - Police Report', Sahara Reporters, 23 December, (accessed 21 July 2021)

Kooijman-van Dijk, A. (2020) 'ENERGIA's Gender and Energy Research Programme: Findings and Experience from Research for Policy', IDS Bulletin 51.1: 91-110, DOI: 10.19088/1968-2020.107 (accessed 20 July 2021)

Lagbaja (2000) 'Suuru Lere', Motherlan' Music

Lakemfa, O. (2015) 'Parliament of the Streets: Mass Strikes and Street Protests that Shook Nigeria in 2012', Abuja: Friedrich-Ebert-Stiftung

Lewis, P. (2018) Africa: Dilemmas of Development and Change, London: Routledge

Lighting Africa (2019) 'A Program Designed to Impact 6 million People’, Washington DC: Lighting Africa (accessed 12 July 2021)

Melaye, D. (2013) 'One year after occupy Nigeria protests' National Mirror, 9 January

Merrill, L. et al. (2019) 'Gender and Fossil Fuel Subsidy Reform: Findings from and Recommendations for Bangladesh, India and Nigeria', The Hague: ENERGIA

Mohammed A.L. (2012) 'Fuel Subsidy Scam: ACN asks PDP Chair to Step Down', Sahara Reporters, 29 July (accessed 27 April 2020)

MPPN (2018) National Multidimensional Poverty Index for Nigeria, Multidimensional Poverty Peer Network, 6 November (accessed 23 April 2020)

Naira Metrics (2019a) 'IMF tells Nigeria to Remove Fuel Subsidies, Discloses Benefits of Decision', 12 April (accessed 27 April 2020)

Naira Metrics (2019b) 'FG replies International Monetary Fund's Fuel Subsidy Removal Request', 16 April (accessed 27 April 2020)

NBS (2018) National Production Estimates, National Bureau of Statistics (accessed 20 April 2020)

Nwachukwu, M.U. and Chike, H. (2011) 'Fuel Subsidy in Nigeria: Fact or Fallacy', Energy 36.5: 2796-801

Ogidan, S. (2020) 'Subsidy Under Buhari Monumental Fraud - PDP', The Independent, 7 April (accessed 23 April 2020)

Ohaegbu, A. (2019) 'Nigerians to Protest in Washington against Buhari's Plan to take New Loans', African Courier, 2 December (accessed 29 April 2020)

Ojoye, T. (2019) 'Nigeria's Fuel Subsidy not helping the Poor — World Bank', Punch, 4 June (accessed 29 April 2020) 
Okonjo-Iweala, N. (2018) Fighting Corruption is Dangerous: The Story Behind the Headlines, Boston: MIT Press

Okonkwo, R. (1995) Protest Movements in Lagos, 1908-1930, Lewiston: Edwin Mellen Press

Oladipo, O. (2021) 'Nigeria’s Daily Petrol Consumption Hits Record High of 93m Litres', Business Day, 5 May (accessed 11 August 2021)

Olisah, C. (2020) 'FG gives Reason Oil Marketers are not yet Importing Petrol, Stops Monthly Price Fixing', Nairametrics, 9 September (accessed 21 July 2021)

Olorunyomi, S. (2013) 'Afrobeat!: Fela and the Imagined Continent', Nairobi: IFRA-Nigeria

OPEC (2020) 'Nigeria Facts and Figures' Organization of the Petroleum Exporting Countries (accessed 1 October 2020)

Oseni, A.L. (2017) 'The Huge Scam that was Nigeria’s Oil Subsidy', Pambazuka News, 8 June (accessed 28 April 2020)

Osunmuyiwa, O. and Kalfagianni, A. (2017) 'The Oil Climax: Can Nigeria's Fuel Subsidy Reforms Propel Energy Transitions?', Energy Research \& Social Science 27: 96-105

Oyedepo, S.O. (2012) Energy and Sustainable Development in Nigeria: The Way Forward', Energy, Sustainability and Society 2.1: 15

Page, M.T. (2016) 'Nigeria's Reform of its State Oil Company will be Cosmetic without Cutting Corrupt Ties', Quartz Africa, 11 March (accessed 27 April 2020)

Popoola, S. et al. (2012) 'Death Toll Hits 16 as Three States Declare Curfew', The Moment Newspaper

Premium Times (2012) 'EFCC Withdraw Charges against Four Oil Subsidy Fraud Suspects', 31 July (accessed 11 August)

Reuters (2015) 'Factbox: Nigeria's \$6.8 Billion Fuel Subsidy Scam’, 13 May (accessed 11 August)

Rice, X. (2012) 'Fuel Gamble Costs Jonathan his Standing. Nigeria’s President Miscalculated by Scrapping Subsidies without Easing the Blow to the Poor', Financial Times, 13 January (accessed 11 August)

Simpson, S. (2007) 'General Strike Over Rising Fuel Price Takes Hold in Nigerian Cities', The New York Times, 21 June (accessed 11 August)

Skutsch, M.M. (2005) 'Gender Analysis for Energy Projects and Programmes', Energy for Sustainable Development 9.1: 37-52

Social Action (2012) 'Fuels of Dissent: Politics, Corruption and Protest over Fuel Subsidy in Nigeria', Port Harcourt: Social Development Integrated Centre (accessed 11 August)

Tha Suspect (2012) Subsidy, CAPitalHill Music (accessed 25 May 2021)

Udo, B (2020) 'Why Nigeria's not among Countries Granted Debt Relief by IMF - Finance Minister', Premium Times, 16 April (accessed 27 April 2020)

USAID (2021) 'South Africa Power Africa Fact Sheet', United States Agency for International Development (accessed 11 August)

USAID (2020) 'Nigeria Power Africa Fact Sheet', United States Agency for International Development (accessed 11 August)

Valassopoulos, A. and Mostafa, D.S. (2014) 'Popular Protest Music and the 2011 Egyptian Revolution', Popular Music and Society 37.5: 638-59

van Blommestein, J. and Hope, S. (2012) 'The Language of Songs: The Utilization of Freedom Songs as a Form of Protest in the South African Anti-apartheid and US Civil Rights Movements', International Journal of the Humanities: Annual Review 10.1: 59-68

World Bank (2014) 'Electric Power Consumption (kWh per capita) - Nigeria', Washington DC: World Bank (accessed 11 August) 


\section{(-) institute of development studies}

Delivering world-class research, learning and teaching that transforms the knowledge, action and leadership needed for more equitable and sustainable development globally.

Institute of Development Studies

Library Road

Brighton, BN1 9RE

United Kingdom

+44 (0)1273606261

ids.ac.uk

Charity Registration Number 306371

Charitable Company Number 877338

(C) Institute of Development Studies 2021 